\title{
Me Prizon (Mes Prisons) Muahezenâmesi ve bu bağlamda Namık Kemal'in tenkit anlayışı üzerine
}

\section{Selçuk ATAY ${ }^{1}$}

\begin{abstract}
APA: Atay, S. (2020). Me Prizon (Mes Prisons) Muahezenâmesi ve bu bağlamda Namık Kemal’in tenkit anlayışı üzerine. RumeliDE Dil ve Edebiyat Araştırmaları Dergisi, (19), 309-338. DOI: 10.2900o/rumelide.752347.
\end{abstract}

\section{$\ddot{O} \mathbf{z}$}

Edebî eleştiri; bir edebî eseri oluşturan yazar ve okuyucunun her ikisini de içine alan entelektüel bir faaliyettir. Bu faaliyet bir taraftan sanatkârın yeteneklerine, zihnî yapısına ve kıymetine dair doğrudan fikir beyan ederken diğer taraftan okuyucunun bir edebî eser karşısındaki tavrını da belirler. Tanzimat döneminden itibaren Batılı anlamda örnekleri görülmüş olan eleştiri günümüze değin pek çok gelişme ve değişme göstermiş bir türdür. Tanzimat dönemi sanatkârlarının tenkit, mülahaza ve muaheze kavramlarını aynı dönem içinde kullandıkları; ancak bu kullanımları sözcüklerin kökenlerini ve Batı'da yeni yeni tanıdıkları “critiqué” sözcüğü arasındaki benzerlik ve farklılıklara dikkat etmeye çalışarak kullandıkları görülür. Eleştirinin günümüzdeki yapıcı ve olumlu alanının kullanım alanına dâhil olmadığı Tanzimat dönemi daha ziyade edebî faaliyetin eksik ve kusurlu yanlarını göstermeye çalışır. Bunun yapılmasındaki temel sebep ise hatanın tekrar etmemesini sağlamaktır. Gazete sayfalarında günlerce devam eden tartışmalara sebep olan bu yorum faaliyeti sanatkârların henüz sübjektif yargılardan kurtulamamış olduğunun da göstergesidir. Bu makalede Recaizâde Mahmut Ekrem’in İtalyan yazar Silvio Pelluci'nin hapishane hatıralarını ihtiva eden eseri Me Prizon (Mes Prisons) Tercümesi ve bu tercüme üzerine Namık Kemal’in yaptığı muaheze üzerinde durulmuştur. Eleştiri sözcüğü yerine Tanzimat döneminde kullanılmış olan tenkit ve muaheze kavramları arasında devrin sanatkârlarında gözetilen farkın anlaşılması ve Namık Kemal'in bir edebî esere bakışının Me Prizon Muahezenâmesi özelinde ortaya konulması amaçlanmıştır. Mecmua-i Ebuzziya'da iki kez tefrika edilmesine rağmen daha evvel tam bir çevirisi yapılmamış olan Me Prizon Muahezenâmesinin günümüz harflerine aktarılması bu makalede ele alınmaktadır.

Anahtar kelimeler: Mes Prisons, Muaheze, Namık Kemal

\section{Me Prizon (Mes Prisons) Muahezenâmesi and in this context on the criticism of Namık Kemal}

\begin{abstract}
Literary criticism; it is an intellectual activity that includes both the writer and the reader who make up a literary work. This activity, on the one hand, expresses a direct idea of the artist's abilities, mental structure and value, and on the other hand, systematizes the reader's attitude towards a literary work. The criticism, which has been seen in the Western sense since the Tanzimat period, is a type that has made many developments and changes until today. The Tanzimat period artists used the concepts of criticism, observance and perseverance within the same period; however, it is seen that they use these uses as the origins of the words and trying to pay attention to the similarities and differences between
\end{abstract} 2257 [Makale kayıt tarihi: 25.02.2020-kabul tarihi: 20.06.2020; DOI: 10.29000/rumelide.752347] 


\begin{abstract}
the word "critiqué" they have just known in the West. The Tanzimat period, where the constructive and positive area of criticism is not included in the field of use, tries to show the shortcomings of the literary activity. The main reason for doing this is to ensure that the error does not recur. This interpretation activity, which causes controversy on the newspaper pages for days, is an indication that the artists have not yet been freed from subjective judgments. In this article, the translation of Me Prizon (Mes Prisons) by Recaizâde Mahmut Ekrem, which contains the prison memories of the Italian writer Silvio Pelluci, and the hypothesis made by Namık Kemal on this translation. Instead of the word criticism, it is aimed to understand the difference observed in the artists of the period between the concepts of criticism and conscientiousness used in the Tanzimat period and to reveal Namık Kemal's view of a literary work in the context of Me Prizon Muahezenâmesi. Although it has been serialized twice in Mecmua-i Ebuzziya, the transfer of the Prizon Muahezenâmesi to today's letters, which has not been fully translated before, is discussed in this article.
\end{abstract}

Keywords: Mes Prisons, Critique, Namık Kemal

\title{
Giriş yahut Tanzimat devrinde tenkit ve muaheze kavramlarının görüntüsü üzerine
}

Şüphesiz bir edebî eserle o eseri merkezine alan edebiyat incelemesi birbirlerinden çok farklı şeylerdir. $\mathrm{Bu}$ ikisi arasındaki farkı belirterek çalışmasına başlayan René Wellek ve Austin Warren, bu iki kavramdan ilkini "bir yaratma" ve "sanat" olarak değerlendirirken ikincisinin ise "bir çeşit bilgi veya öğrenme" olduğunu söyler (2001: 1). Dolayısıyla bu durum, günlük dilden farklı bir dili malzeme olarak kullanan edebî eserin "incelenme"si, "takdir" edilmesi ve kıymetinin ortaya konulması kavramların birbirinden ayrılmasını gerektirdiği gibi incelemede kullanılacak bir üstdilin de varlı̆̆ını zorunlu kılacaktır. René Wellek'in bir bilim olarak edebiyat incelemesi ile "takdir etme" ve "değerlendirme" kavramlarını birbirinden ayırması modern edebiyat teorilerinin geldiği yeri göstermesi bakımından önemlidir. Göstergebilimin yapıbozumcu bir şekilde algıladığı inceleme kavramı betimsel, yöntemsel ve bilimkuramsal düzey olmak üzere üç farklı düzeyi içinde barındırır (Rifat, 2013: 228). İnceleme nesnesinin malzemesiyle bilim olarak edebiyat incelemesinin kendisini ifade vasitası olan dili birbirinden ayıran bu kavram her iki unsurun da üsluptan yönteme değin kendisini doğru yerde konumlandırmasına yardım etmektedir.

Klâsik dönemde tenkit, muaheze gibi kavramların sık sık birbirinin yerine kullanıldığını, daha doğrusu ifade ettikleri anlam alanları bakımından birbirlerinden keskin bir şekilde ayrılmadıklarını hatırlamakta fayda vardır. Klâsik edebiyatımızda daha ziyade şiir ve onun şeklî hususiyetleri üzerine söylenen, nesir yazılarını ise çoğu zaman görmezden gelen kimi değerlendirmeler modern anlamda bahsedilen "ilmî araştırma"nın oldukça uzağında kalan metinlerdir. Arap edebiyatında "nakd" sözcüğü ile karşllanan tenkit terimi hakkında Tahirü’l-Mevlevi’nin Edebiyat Lügati’nde "nazmın kusurlarını bildiren ilmin adıdır" (1995: 113) şeklinde açıklamada bulunması kavramın o dönemde ihtiva ettiği türleri göstermesi ve aynı zamanda "kusur" sözcüğünden hareketle edebî türe bakış açısını ortaya koyması bakımından önemlidir. Daha ziyade eserlerin dibace bölümlerinde veya tezkirelerde karşımıza çıkan bu değerlendirme yazılarının başlı başına bir tür olması Tanzimat döneminde mümkün olmuştur.

Tanzimat döneminde Fransız edebiyatının yoğun tesiri, edebî türlerin biçimlenmesinde etkili olduğu gibi o eserlere bakışın da sistematik bir hâl almasını sağlamıştır. Fransızca "critiqué" sözcüğünün karşllığı olarak "nakd” sözcüğünden türeyen "tenkit” sözcüğünün kullanılması Servet-i Fünûn nesliyle başlamıştır (Ercilasun, 1998: 11). Ancak bu sözcüğün Tanzimat ediplerince de bilindiği, öte yandan anlam alanının Servet-i Fünûn neslinden farklı bir yere işaret ettiğini belirtmek gerekir. Nitekim 
Şemsettin Sami Kâmus-ı Türkî'de "tenkit” sözcügü için "Edebiyat-ı Cedîde'de Fransızların critique dedikleri muaheze-i edebiyye manasıyla kullanılmaya başlamış ise de, Arabî'de 'nakd' maddesi tefil babından gelmediğinden bunun yerine 'intikad' ve 'tenkad' kullanılsa daha doğru olur.” (2001: 445) açıklamasında bulunur. Şemsettin Sami "muaheze" sözcüğü için ise "bir şahsın veya eserin nekâyısını dermeyan ederek itiraz etme, inkad” (2001: 1423) tanımını vermektedir. Şemsettin Sami’nin muaheze ile tenkit sözcüğünü anlam bakımından denk tuttuğu, ancak sadece dilbilgisi açısından kullanıma dair bir itirazının olduğu görülmektedir.

Kendisini "Şinasi mekteb-i edebinden" gören Ebuzziya Tevfik, 15 Cemaziyelevvel 1315 (11 Kasım 1897) tarihinde yazdığı yazıda "tenkit" ile "critiqué" sözcükleri arasında "hiçbir münasabet" olmadığını belirterek Namık Kemal’in "muaheze" sözcüğünü "critiqué hükmünü şamil bir kelime-i istılahiye olduğuna ve âsâr-ı eslafta bu mana”da kullanıldığını söyler (1315: 1257). Ardından Namık Kemal'in Münif Paşa'ya yazdığı mektubu bu cümlesine delil olarak gösterir:

\begin{abstract}
“Tenkit lafzı critiqué yerinde kullanılmak caiz değildir sanırım. O mütalaa üzerineydi ki bazı ulemayı selefin eserlerinden iktibasın critiqué fikrini 'muaheze' lafzıyla tercüme etmiştim. Nazar-ı hakîm-i âsâfanelerine mestur değildir ki 'tenkit' bir şeyin iyisini fenasından ayırmakta bir hüküm vermek mazmununu şâmil oluyor. Muaheze ise her şeyi fena tarafından görerek bir mütalaa beyanından ibarettir." (1315: 1257)
\end{abstract}

"Bâtılı hakikatten" ayırmakta "en sâlim" yolun da bu muaheze kavramı etrafında oluştuğunu söyleyen Namık Kemal'in görüşlerini tasdik eden Ebuzziya Tevfik, "critiqué” sözcüğünün içini iyiyi kötüden ayırma şeklinde doldurmuş olmaktadır. Ona göre tenkit ise eseri izah eden, ancak onun hakkında bir hüküm vermekten uzak bir eylem olarak görülmelidir. Dolayısıyla Tanzimat sanatkârları için asıl olan sonunda belirli değer yargılarına göre bir hüküm vermek, bir kıymet takdir etmektir. Bunun da yolu eserin daha ziyade kötü yönlerine dikkat edilerek hakikatin ortaya çıkarılmasıyla mümkündür.

Ebuzziya Tevfik, Recaizâde Mahmut Ekrem'in İtalyan yazar Silvio Pelluci'nin Me Prizon (Mes Prisons) adlı eserinin tercümesi üzerine Namık Kemal’in yaptığı muahezeyi yayımlarken yaptığı açıklamada Volter'den hareketle aynı görüşleri savunmuştur. Ona göre muaheze "manaya ve bir dereceye kadar fikre masruf olabilir ise de hiçbir vakit mahiyet-i eserle beraber tayin-i hakikat için kullanılan bir vasıta müessirin şahsına taalluk ettirilmemelidir." (1302: 1411)

Son olarak Recaizâde Mahmut Ekrem Bey'in bu iki kavram arasındaki görüşlerine değinmek gerekmektedir. Menemenlizâde Tahir Bey'in Elhan adlı eseri hakkındaki görüsslerini Takdir-i Elhan adlı kitabında sıralayan Ekrem Bey; eserin vezninde, kafiyesinde veya mülahazalarında bulunan kusurlara dair hasetle yazılan yazıların veya şairin/sanatkârın şahsına dokunan hususların muaheze olmadığını belirtir. Ekrem Bey'e göre gerçek bir muaheze için "âlim", "hakîm", "ciddi” ve "halisane" sıfatlarını bünyesinde toplayan insanların "nazar-ı hâkimâne, sür'at-i intikal, tabiat-ı şâirâne, kudret-i kalemiye, hüsn-i üslup, teşhis-i bedâyi, dikkat-i temyiz, zarafet-i efkâr, rikkat-i his" sahibi olması gerekir ki Ekrem Bey’e göre bu sıfatları haiz bir muahiz her devirde ancak bir iki tane yetişir (1301: 33-34).

Görüleceği üzere Tanzimat sanatkârları klâsik edebiyatın eleştiri anlayışından sıyrılıp yeni edebî türlerin yeni bir bakış açısıyla değerlendirilmesi hususunda sarih fikirlere sahiptirler. Ancak türlerin yeni yeni tanınıyor oluşu isimlendirilme noktasında kimi fikir ayrılıklarına sebep olmaktadır. Bu ayrılıklardan biri de muaheze ve tenkit kavramlarının kullanımına dairdir. Söz konusu kavramların kullanımında Namık Kemal, hususiyle muaheze sözcüğünü tercih etmektedir. Bir eseri değer yargısı vermeden, kıymet biçmeden inceleme anlamında kullanıldığını söylediği tenkit sözcüğü yerine asıl olanın iyiyi kötüden ayırmak olduğu düşüncesiyle muaheze yapılması gerektiği görüşünü savunmaktadır. Zira edebiyatın 
istenilen yönde gelişebilmesi için “iyi” olanların gösterilmesi, "fena” olanların ise eleştirilerek doğru yere yönlendirilmesi gerekmektedir.

\section{Me Prizon (Mes Prisons) ve Namık Kemal'in Muahezenâmesi}

İtalyan şair ve oyun yazarı Silvio Pellico'nun 1832 yılında yayımlanan Le Mio Prigoni (Benim Hapishanelerim) adlı eseri sanatkârın yaklaşık on sekiz yıl kaldığı hapishane hatıralarından oluşur. Vincenzo Monti, Alessandro Manzoni gibi devrin milliyetçi sanatkârlarıyla birlikte adı anılan Pellicio'nun bu eseri, 1856 yılında Mes Prisons adıyla Fransızcaya tercüme edilmiştir. Recaizâde Mahmut Ekrem ise 1291 (1874) tarihinde eseri Türkçeye tercüme etmiştir.

Ekrem Bey 1291 (1874) tarihinde yayımlanan Me Prizon'dan önce telif eserlerinin yanında tercümeler de yapmış, 1872 ylında Chateaubriand'dan Atala tercümesini ve hemen ardından aynı yıl çeşitli çevirilerini topladığı Müntehabat-ı Edebiyye adlı eserini yayımlamıştır. Ancak Me Prizon'un tercümesi bu eserlerin yayımından öncedir. Me Prizon'un mukaddimesinde belirtildiği üzere tercümeye beş yıl önce (1869), sanatkârın "Fransızcaya yeni heves ettiği zaman" başlanmıştır. On dokuzuncu mebhasa kadar süren bu ilk kalem tecrübesi Terakki gazetesinde yayımlanmıştır. 3 Yarıda kalan bu tercüme, sanatkârın "evrak-ı perişan" arasında kaybolup gitmesine "gönlü" razı olmadığından tamamlanarak 1874 yllında yayımlanmıştır.

Recaizâde'nin tercüme veya telif olarak yayımladığı eserlere bakıldığında çalışmalarının merkezine daima estetik bir bakış açısını yerleştirdiği görülür. Yalnızca Me Prizon tercümesi siyasi kişiliği olan bir sanatkârın eseri olarak dikkat çekmektedir. Ahmet Hamdi Tanpınar, Recaizâde Mahmut Ekrem'in, siyaset noktasında pasif bir tutum sergilemesine rağmen bu eseri 1291 (1874) yılında Me Prizon 4 adıyla Türkçeye aktarmasını o dönemde Magosa'da sürgünde olan Namık Kemal'in durumunu "protesto etmek için seçilmiş bir esere benzer” (1997: 477) şeklinde yorumlar.

Eserin yayımlanmasından sonra Namık Kemal eser üzerine bir "muahezenâme" kaleme alır. Ekrem Bey’e yazdığı bu muahezenamenin ön sözünde asıl değerlendirmenin tercüman ve tercüme üzerine olmadığını, daha ziyade Silvio Pelluci'yi değerlendirdiğini söyler. Yazdığı tiyatro eserinin oynanmasından sonra Magosa'ya nefyedilen Namı Kemal'in yine bu sürgünde iken okuduğu ve değerlendirdiği Me Prizon tercümesi üzerine yazdığı "muahezenâme", Namık Kemal'in yalnızca edebiyat üzerine görüşlerini yansıtmakla kalmaz, onun hayatının ve sanatının merkezine koyduğu vatan ve vatanperverlik kavramının anlaşılmasını sağlayan bir metin olarak da karşımıza çıkar. Ahmet Hamdi Tanpınar'ın da belirttiği üzere "Kemal'in cemiyet ve hayat karşısındaki vaziyetini hiçbir eser bu kadar sarih gösteremez” (2000: 236). Tanpınar'ın kastettiği sarihlik, vatanperver bir sanatkârın toplum veya şahsi hayatında zaafların olmamasına dairdir. Tercümanın veya yapılan tercümenin tenkidinden daha ziyade eserin merkezinde yer alan Silvio'nun tenkit edildiği eserin bu durumu Namık Kemal'in "zaafın yokluğundan gelen bir zaaf”tan kaynaklanmaktadır (2000: 237).

\footnotetext{
2 Sanatkârın daha evvel Terakki ve Hakayıku'l-Vekayi mecmualarında yayımlanan ve Fransız şairlerinden yaptı̆̆ tercümeleri içeren eserin basımı ve nitelikleri için bkz.: Sançar, Nejdet (1956). "Recaizâde Ekrem’in Eserleri ve Eserlerinin Çeşitli Basımları”, Türk Kütüphaneciler Derneği Bülteni. C. V., S. 2, Ankara, s. 145-146.

3 Nejdet Sançar Terakki gazetesinde yayımlanan bu kısmın başlangıç tarihini 6 Cemaziyülevvel 1286 olarak verir. Ayrıca ilk mebhasla birlikte sanatkârın bir mektubunun da yayımlandığını belirtir (1956: 145). Burada Sançar'ın verdiği bilgi Me Prizon'un mukaddimesinde Recaizâde Mahmut Ekrem Bey'in verdiği bilgidir. Ancak o tarihteki gazete ve dergiler taranmış, bahsedilen mektuba ve tercümenin tefrikalarına ulaşılmamıştır.

4 Recaizâde Mahmut Ekrem (1291/1874). Me Prizon. İstanbul: Matbaa-i Tasvir-i Efkâr.
}

Adres

Kırklareli Üniversitesi, Fen Edebiyat Fakültesi, Türk Dili ve Edebiyatı Bölümü, Kayalı Kampüsü-Kırklareli/TÜRKIYYE e-posta: editor@rumelide.com
Adress

Kırklareli University, Faculty of Arts and Sciences, Department of Turkish Language and Literature, Kayalı Campus-Kırklareli/TURKEY e-mail: editor@rumelide.com 
Me Prizon Muahezenâmesi ilk olarak Mecmua-i Ebuzziya'nın 13025 tarihli 45. cüzünden itibaren tefrika edilir. Oldukça kısa tutulan bu tefrika hakkında Ebuzziya Tevfik Bey, doğrudan tercümeye ilişkin kısımların yayımlandığını söyler. Bu tefrikadan yaklaşık yirmi yıl sonra yine aynı dergide yayımlanan muahezeden $^{6}$ anlaşıldığına göre ilk tefrikada Namık Kemal'in hayatı hakkındaki kimi yerlerin çıkarılmasının yanında devrin siyasi ve sosyal şartları gereği kimi argo sözcüklerin atıldığı, "inkılap, cellat” vb. gibi sözcüklerin de metinden çıkarıldığı görülmektedir. Eserin tercümesindeki elli mebhasın her biri üzerinde görüşlerini aktaran Namık Kemal’in üzerinde durduğu konular şu şekilde sıralanabilir:

Tercüme Üzerine

Tercümenin edebî yönü üzerine eleştiriler

Tercümenin ahlaki yönü üzerine eleştiriler

Mütercim Üzerine

Mütercimin sanat endişesi üzerine eleştiriler

Mütercimin sözcük seçimi üzerine eleştiriler

Eser Üzerine

Silvio'nun karakterine dair eleştiriler

Silvio'nun ahlak mülahazası üzerine eleştiriler

Silvio ve vatan kavramı üzerine eleştiriler

Eserde anlatılanların kendi hayatı üzerine mukayesesi

Namık Kemal'in tercüme ve mütercim üzerine görüşleri daha ziyade sözcük seçimi üzerinde yoğunlaşmaktadır. Seçilen sözcüklerin ahlaki, dinî ve edebî boyutları Namık Kemal'in dikkatlerinin merkezini oluşturmaktadır. 1292 yılında Magosa'dan Abdülhak Hamit'e yazdığı mektupta7 tercüme için "hem mütercimin hem de edebiyatımızın pek çocukluk zamanına tesadüf etmiştir" (2015: 441) cümlesi bu konudaki kanaatlerinin hülasası olarak okunabilir. Örneğin "lisan-ı avam" üzere şeklinde tabir ettiği "gidi” sözcüğünün eserde kullanılması hakkında şunları söyler:

"Mamafih galatât-ı avamın istimaline kat'a tariz etmemekle beraber bu yolda müstehcen tabirlerin edibane yazılmış bir eserde bulunmasında cevaz tasavvur edemem. Hususa ki münasebet-i makam dahi gerek zamanın ve gerek cihanın, öyle tahkirli bir sözle tavsifine lüzum göstermiyor. Zamanda sürat-i güzerânın, cihanda kesret-i inkılabın vücudu neden ikisinin de hicvini iktiza etsin."

Görüldüğü üzere Namık Kemal edebî bir eserde kullanılacak müstehcen bir sözcüğün seçimine "cevaz” vermemektedir. Öte yandan burada bir şart koşarak "münasebet-i makam”n da böyle bir sözü kullanmaya ihtiyaç gerektirmediğini söylemesi sözcüğü bağlamıyla birlikte değerlendirdiğini, yalnızca ahlaki bir mülahaza ile karşı çıkmadığını göstermektedir. Ayrıca sanatkârın tenkitleri dinî bir duyarlılığın da varlı̆̆ını daima hissettirmektedir:

“Tercümede nazar götürür bir hayli şeyler var. 'Ezcümle ahvâl-i müşkilede Cenâb-ı Hak ile halisane istişare eylemek' ibaresindeki istişare şive-i lisan hükmünce hem Cenâb-ı Hak'tan taleb-i işaret ve hem de haşa Allâmü'l-guyûb'a talim-i hikmet gibi birtakım mana ifade ediyor. 'İstişare' kelimesi mana-yı mevzuu itibariyle taleb-i işaret manasına istimal olununca "Cenâb-ı Hak ile" yerine Cenâb-1 Hak'tan ibaresi kullanılmak, yani Cenâb-ı Hak'tan halisane istişare denilmek iktiza ederdi itikadındayım."

5 Eserin ilk yayımı için bkz.: Мecmua-i Ebuzziya, Sene 1302 (h), cüz 45, s. 1409-1417; cüz 46, s. 1441-1452; cüz 47, s. 14731483).

$6 \quad$ Eserin ikinci yayımı için bkz.: Mecmua-i Ebuzziya, Sene 1330 (h), cüz 129, s. 8-14; cüz 130, s. 37-43; cüz 131, s. 91-94, cüz 132, s. 114-119, cüz 133, s. 149-154, cüz 168, s. 175 .

25 Muharrem 1292 (3 Mart 1875) tarihli mektup için bakınız: Ebuzziya Tevfik (2015). Nümûne-i Edebiyyât-ı Osmaniyye. (haz.) Furkan Öztürk. İstanbul: Dün Bugün Yarın, ss. 435-448. 
Namık Kemal'in mütercim üzerine dikkatleri Recaizâde Mahmut Ekrem'in sanat yapmak endişesi ile yaptığı tercihlerde yoğunlaşır. Metnin tamamında eş anlamlı fakat kafiyeli olarak kullanılan sözcüklerin gereksizliğini vurgular:

"Esrâr-1 hafâyâ", "vahtiyât ve intibah", "havf ve haşyet", "farz ve takdir", "me’âs ve vazife", "nesâyih ve vesâyâ" terkiplerinde olan ikișer kelimenin birer tanesi zaid olduğu tarife hâcet olmamak gerek."

Öte yandan sözcüğ̈̈n kafiyeli de olsa anlamdan ve mantıktan uzak olması Namık Kemal'in itiraz ettiği konulardandır:

"Hâmisen 'def ve teb'îd' kelimelerinin yine biri zâid olduğu gibi onun kafiyesi olarak kullanılan 'hayat1 cedîd' terkibinde sıfat mevsuf mutabakatı yok. Vakıa itimadımca bu mutabakat kat'iyyü'l-lüzum değildir; fakat kafiye-perverâne ve binaenaleyh edebiyat-ı atikaya mail bir tarzda yazılan şeylere de tezyinattan evvel kaideye ittiba etmek iktiza edeceğini tarif iktiza etmez."

Recaizâde Ekrem Bey'e yapılan eleştirilerden bir tanesi de Ekrem Bey’in klâsik edebiyata bağlllı̆̆ üzerinedir. Namık Kemal burada "Acemâne" düşen terkipleri eleştirirken diğer taraftan talebesi konumunda olan bir isme nasihatler vermeyi de ihmal etmez:

“Saniyen 'me’yusü'l-fuâd' terkibi hiç isti'mâl olunmamıș olduğu hâlde fuâd lafzının ilavesiyle me’yus kelimesine bir zâid mana inzimam etmediğinden kabul ve ihtiraına dahi edebiyatça katiyen ihtiyaç yoktur. Dikkat ediyor musun! Edebiyat-ı atikadan bütün bütün tecrit etmedikçe kafiye zarureti bayağı para zarureti gibi insanı ne kadar münasebetsiz şeylere sevk ediyor.”

Klâsik edebiyatın katı kuralları yüzünden sanatkârların mecbur kaldıkları durumu bu şekilde özetleyen Namık Kemal muahezesinin büyük bir kısmını eserin sahibi olan Silvio Pelluci'ye ayırır. Eser üzerine değerlendirmelerinde sanatkârın her fırsatta ağlaması Namık Kemal’in en büyük eleştirisidir:

"Mübarek ağlamakta bu kadar suûbet gördüğü hâlde hapse girer ağlar, babasını görür ağlayacağı gelir; ahbabiyla görüşür kendini ağlamaktan zorla men eder. Demek ki girye hususunda biraz da nefsince suhulet görseymiş selam verseler ağlayacakmış!"

Öte yandan "Kont Bru’yu görmekle ağlamaya kalkışacak kadar teessür nedir? Silvio otuz yaşında [bir inkılab-cûy] iken adeta çocuk mizacında imiş ya!" diyerek eleştirdiği bir inkılap taraftarı olan sanatkârın ağlamasını "çocuk mizacı" olarak tanımlayan ve edebî bir eserde bulunmasını eleştiren Namık Kemal, sanatkârın din üzerine görüşlerini hem Hıristiyanlık ve hem de Müslüman akideleri açısından yorumlamaktadir:

"Fakat zaman-ı asayiş ve saadette umûr-ı diniyesini düşünmeyip de bir felakete uğradı̆̆ı gibi hani din derler bir şey var idi, bir de oraya müracaat edeyim; belki necatıma vesile olur, diyerek diyanetle tecrübe-i tali'e kalkışmak da dinsizlikten aşağı kalır denaetlerden değildir.”

Dinî hassasiyete sahip olarak bilinen bir sanatkârın eserde gösterdiği tutarsızlıklara da değinen Namık Kemal vatan ve millet yolunda çalışan insanlarda görülen kalbî zaaflar hakkında mütercimi de uyarmaktadır:

"Silvio gibi gerek zekâvet ve gerek terbiyece mütemeddin bir millet içinde fevkalade bir şöhrete mazhar olmuş bir adamın velev muvakkat olsun o kadar sakîm fikirlere düşebilmesine ne kadar taaccüb olunsa şayeste değil midir? Dikkat et ki zaaf-ı kalp en kemalli zannolunan insanları ne mertebelere tenzil ediyor!"

Namık Kemal'in "hubb-ı vatan" tamlaması etrafında kurulan edebî eser telakkisine de burada dikkat çekmek gerekmektedir. Tanpınar bu eser hakkında yaptığı değerlendirmesinde "Kemal'in cemiyet ve 
hayat karşısındaki vaziyetini hiçbir eser bu kadar sarih gösteremez.” (2000: 236) der. Bu değerlendirme Silvio’nun vatan telakkisi hakkında gösterdiği zaaflara dair Namık Kemal'in eleştirilerinde gösterdiği hücumlara dairdir. Aile sevgisine hakkını teslim etmekle beraber "Kaza ile olsun vatanı için kaleminden bir kelime-i teessür damlamak yok mudur?” şeklinde eleştirisini yönelten Namık Kemal, sanatkârın teessürünü, ağlamasını anlamlandıramaz:

\begin{abstract}
"Sonra niçin galebe etmiş de babasını, anasını düşünerek ağlamamış! Evet hubb-ı aile de bir hiss-i mukaddestir. Fakat hubb-1 vatana galip tutulmak lazım gelmez. Nitekim sehâvetin tarif-i diğeri olan muhabbet-i fukara da memduh bir histir. Lakin hubb-ı aileye takdim olunmak iktiza etmez. Hizmeti vatan yolunda felakete uğramış bir gayurun aile hasretiyle ağlaması ailesini zaruretten kurtarmak için malını telef etmiş bir sahînin tasadduk hasretiyle girye-bâr olmasına benzer. Ben de Avrupa'ya giderken pederimden, ailemden ayrıldım. Fakat hatta ayrılacağım saatte dahi gözüme vatanın haritai azametinden başka bir şey görünmez, fikrime vatanın sevâbık-ı fâhiresinden başka bir şey hutûr etmez, gönlüme vatanın ikbâl-i istikbalinden başka bir hiss tahakküm eylemezdi. Aile muhabbeti dahi hissiyat-ı ulviyesinin eczasından biri olan koskoca vatanımdan yine vatanım için ayrıldığıma ağlamayacağım da ailemden ayrıldığıma $\mathrm{mı}$ ağlayacağım?"
\end{abstract}

şeklinde sorduğu soru yalnız Silvio'ya ilişkin bir soru değil, Namık Kemal’in toplum hayatındaki yerini göstermesi bakımından mühimdir. Görüleceği üzere Avrupa’ya gidişini “vatanımdan yine vatanım için” şeklinde tanımlayan Namık Kemal, ağlamak hasletini Rabbe karşı acizliğin ifadesi olarak görmekte ve bunun haricindekileri yanlış bulmaktadır. Ayrıca vatanın hürriyeti için yapılan mücadelelerde başa gelen belaların ulvî olduğunu söyleyerek şikâyet etmenin, szzlanmanın yanlışlığını da şöyle belirtir:

“Acaba Silviyo hürriyet-i vatan namına irtibat hâsıl ettiği politika yolunda bir zindan-ı belaya düşmüş iken vicdanına nasıl galebe etmiş de mecruh-ı hançer-i zulmü olduğu maşukasına karşı sükût-ı edibane ile izhâr-ı infial eden âşık-ı sadık gibi politika yüzünden uğradığı felaketlere mukabil sükût ile teskin-i hararet teselli-i garibini ihtiyar eylemiş! Ne kadar mukteza-yı hâle mugâyir teşbih! Maşukasının siteminden şikâyet etmemek başka, aşk yolunda ağyar elinden çekilen felaketleri sükût ile geçmek yine başka. Bir vatanperverin vatanı için en şiddetli bir ıstırap içinde bulunduğu ve hususiyle vatanını kendinden mustarip bir hâlde gördüğ̈̈ zaman hissedeceği teessürlerden daha ulvi, daha şâirâne, daha hazin acaba dünyada bir şey var mıdır?”

Vatan sevgisi ve vatan yolunda hizmet etme hususu muahezenamenin çeşitli yerlerinde Namık Kemal'in kendi hayatından örnekler vermesi ile devam eder. Edebiyatı halka hizmet yolunda bir vasita olarak gören Namık Kemal bu vasıtanın kişinin hayatı ile özdeşleşmesi gerektiği fikrindedir:

“Avrupa'ya gittiğim sırada ben de ailemden ayrıldım, hatta müteehhil idim. Hatta bir de hayatımdan
kıymetli bir kızım vardı. Ve hatta başımda dünyada en şiddetlilerinden bir sevda da mevcut idi.
Cümlesine mütehassir gittim. En sonraki mülakatım da seninle idi. Gözümde bir damla yaş yahut
rengimde bir tagayyür gördün mü? Hiç fedakârlı gibi merdânegî-i mücessem vasfına dünyada her
şeyden ziyade layık olan bir hiss-i âlînin mahkûmu olanların gözünde tıflane bir feryad-ı bî-sadadan
ibaret olan girye nereden hâsıl olur? Avrupa'da Silvio'nun şikâyet ettiği hasretlerin umumuna
maziyadeten müptela idim. Gönlüme hiçbir vakit rikkat bile gelmedi. Yalnız bir kere az kaldı sevda
getirecektim. Ona sebep de kendi hâlim değil, tervic-i maksatta fırkanın gösterdiği zaafla
münasebetsizliklerdi. Hubb-ı vatanın galebe-i mutlakasına şimdiki hâlimde o kadar deliller gördüm
ki mesele indimde adeta bedîhiyet kuvvetini buldu, diyebilirim.”

Son olarak Namık Kemal'in eseri okurken yaptığı eleştirilerde ölçüyü büyük oranda kendi hayat tecrübesi ile sağladığını söylemek gerekir. Çoğu zaman "nefsimde tecrübe ettim", "vicdanıma tatbik ettim" gibi cümlelerle başlayan ifadelerde eserin içeriğine dair eleştiriler yapıldığı görülmektedir:

“Silvio'nun mahpus iken ilk gece uykudan uyanmakta olan dehşet hakkındaki hissini de vicdanıma tatbik ettim; doğru bulmadım. Ben Hapishâne-i Umumi’ye ilk gittiğim gece on saatten ziyade uyku uyudum. Sabahleyin dahi bizim evde yattığım gecelerin ekserinden daha sakin, daha rahat kalkmıştım. Her şeyden evvel zihnime arkadaşlarımın hâli geldi.” 


\section{Sonuç}

Tanzimat dönemi yalnız bir devrin adı değil toplum hayatında da pek çok köklü yeniliğin adı olan büyük bir medeniyet değişiminin adıdır. Taraftar olunan hususiyetlerin yanı sıra karşı çıkılan yeniliklerin ve uyarılan durumların olduğu bu dönemde görülen değişimlerin en büyüklerinden biri de edebiyata aittir. Sanatkârlar bir yandan ilk defa karşılaştıkları eserlere uyum sağlamaya çalışmakta diğer taraftan şekil ve içerik yönünden değişen türleri halka tanıtmaya çalışmaktadırlar. Şüphesiz böylesine bir ortamda ortaya çıan en mühim eksiklik yapılan edebî çalışmaların eleştirisi olmaktadır. Klâsik kültürden bir mirasla ilerlemesi mümkün olmayan bu tür Tanzimat döneminde en büyük atılımını Namık Kemal'le birlikte yapar. Namık Kemal'in klâsik edebiyat taraftarlarına dair eleştirilerinin yanı sıra modern anlamda eser veren, tercümeler yapan sanatkârları da eleştirmesi türün sistemli bir şekilde ilerlemesi için önemli bir gayret olarak belirir.

İtalyan yazar Silvio Pellico'nun eserini Fransızca'dan tercüme eden Recaizâde Mahmut Ekrem'in eserine yazılan Me Prizon Muahezânemesi böyle bir gayretin tezahürü olarak görülmektedir. Namık Kemal eseri eleştirirken eleştirisini üç bölüme ayırmış, tercüme ve mütercim için söylediklerini sınırlı tutarken eleştirisinin büyük bir bölümünü metnin içeriğine yöneltmiştir. Bunu yaparken sübjektif ifadelerden, kendi hayatı ile tartılan ölçülerden yararlanan Namık Kemal'in bir edebî eser üzerinde konuşurken sanatkârane kaygılarından ziyade üslupla konunun örtüşmesine dikkat ettiği, vatana ve millete hizmet yolunda bir eser olup olmamasını irdelediği, ahlaki ve dinî konuları metnin merkezine çektiği görülmektedir. Aşağıdaki metin günümüz harflerine eksiksiz olarak ilk kez aktarılmaktadır. ${ }^{8}$ Çalışma bu yönüyle Namık Kemal’in edebî esere bakışını ve tenkit anlayışına katkı sunmaktadır. Öte yandan bu katkının edebiyat tarihi açısından mühim bir yer tutacağı düşünülmektedir.

\section{Kaynakça}

Ebuzziya Tevfik (1315/1897). "Muaheze”, Мecmua-i Ebuzziya. Cüz. 45, ss. 1409-1411.

Ebuzziya Tevfik (1315-1897). "Muaheze ve Tenkit Kelimelerine Ait İzahat”, Mecmua-i Ebuzziya. Cüz. 72, ss. 1256-1259.

Ebuzziya Tevfik (2015). Nümûne-i Edebiyyât-ı Osmaniyye. (haz.) Furkan Öztürk. İstanbul: Dün Bugün Yarın.

Ercilasun, B. (1998). Servet-i Fünûn'da Edebî Tenkit. İstanbul: Millî Eğitim Bakanlığı.

Namık Kemal (1302/1884). "Me Prizon Muahezenâmesi”, Mecmua-i Ebuzziya. İstanbul, cüz 45-47.

Namık Kemal (1330/1912). "Me Prizon Muahezenâmesi”, Мecmua-i Ebuzziya. İstanbul, cüz 129-134.

Recaizâde Mahmut Ekrem (1291/1874). Me Prizon. İstanbul: Matbaa-i Tasvir-i Efkâr.

Recaizâde Mahmut Ekrem (1301/1885). Takdir-i Elhan. İstanbul: Mahmut Bey Matbaası.

Rifat, M. (2013). Açıklamah Göstergebilim Sözlüğü. İstanbul: Türkiye İş Bankası.

Sançar, N. (1956). "Recaizâde Ekrem’in Eserleri ve Eserlerinin Çeşitli Basımları”, Türk Kütüphaneciler Derneği Bülteni. C. V., S. 2, Ankara.

Şemsettin Sami (2001). Kâmûs-ı Türkî. İstanbul: Çağrı.

Tahirü’l-Mevlevi (1994). Edebiyat Lügati. (haz.) Kemal Edip Kürkçüoğlu, İstanbul: Enderun.

Namık Kemal'in yazdığı bu muahezenamenin bir kısmı Prof. Dr. Kâzım Yetiş tarafından günümüz harflerine aktarılmıştır. [Yetiş, Kâzım (1996). Nâmık Kemal'in Türk Dili ve Edebiyatı Üzerine Görüşleri ve Yazıları. İstanbul: Alfa, ss. 255-274.] Yetiş, çevirisine kaynak olarak Muahezenâme'in ilk baskısını göstermiş, ancak ikinci tefrikayı esas almıştır. Ayrıca Fevziye Abdullah Tansel de eserin Namık Kemal'in hatıralarına dair olan bazı kısımlarını günümüz Türkçesine aktarmıştır. [Tansel, Fevziye Abdullah (1940). "Namık Kemal'den Parçalar”. Ülkü. C. XVI, S. 94, ss. 326-335.] 
Tanpınar, A. H. (1997). 19'uncu Asır Türk Edebiyatı Tarihi. İstanbul: Çağlayan.

Tanpınar, A. H. (2000). Edebiyat Üzerine Makaleler. İstanbul: Dergâh.

Tansel, F. A. (1940). “Namık Kemal'den Parçalar”. Ülkü. C. XVI, S. 94, ss. 326-335.

Wellek, R.; Warren, A. (2001). Edebiyat Teorisi. (çev.) Ömer Faruk Huyugüzel, İzmir: Akademi.

Yetiş, K. (1996). Nâmık Kemal’in Türk Dili ve Edebiyatı Üzerine Görüşleri ve Yazıları. İstanbul: Alfa. 


\section{ME PRISON MUAHEZENÂMESI}

\section{Muaheze $^{9}$}

Hayli zamandan beri âdet hükmüne girmiş ise de hele son asırda fevkalade bir surette intişar eylemiştir.

Muahezeler ekseriyet üzere hasûd rakipler tarafından icra olunur. Mesela Racine'in Facia'ları taklidi nâkâbil âsâr-ı mükemmeleden oldukları hâlde yine kâffesi dûçâr-ı muaheze olmuştur. Çünkü rukabâ, Racine’in ihrâz eylediği şeref ve imtiyaza bir türlü tahammül edemezlerdi.

Filhakika bedâyi-i nefîse erbabı âsâr-ı bediayı muaheze edebilir. Lakin şu şart ile ki muâhiz olan zat seyyiât-ı ahlak ashabından olmasin.

Bir muâhiz lazım olduğu kadar dirayet ve malumat ve bununla beraber hüsn-i tabiat sahibi olduktan başka bî-taraf ve adil bulunmalıdır. Böyle sıfat-ı mükemmeleyi cami’ bir muâhiz bulmak ise cidden müşküldür.

Zamanımızda Avrupa'da muâhizlik adeta başlı başına bir sanat hükmünü almıştır. Eya muahizler ne yapiyorlar?

Avrupa'da bâzâr-ı iştihara çıkan eserleri muaheze ile meşgul oluyorlar. Daha doğrusu para kazanmak için müellefât-ı makbuleyi tezyif ve ele almaya değeri olmayan âsârı takdir ediyorlar.

Cizvit mesleğini terk ile muharrirliğe sülûk etmiş olan Goyo Defonten en ziyade sahib-i fazl ve kemal olan zevata tariz eder ve yeni çıkan riyaziye ve hikmet-i tabiiyeye dair müellefâtı okumaksızın muahezeye cüret eder idi. Hatta bir gün polis nâzırı kendisini tevkif ile istintak ettiği sırada "Niçin böyle mezmum bir sanatla iştigal ediyorsun?" sualini irad eylediğinde merkum: "Ne bileyim! Medar-ı maişetim ondan ibarettir" cevabını vermiş imiş.

Kendisinden sonra bu vazife ile Freron namında yine bir Cizvit kaçkını meşgul olmaya başladı. Bu şerrü’l-halefin yazdığı bir muaheze-nâme de şu "Sultan Mehmet Han-ı Sani zamanında idi ki Araplar Avrupa'ya dâhil oldular.” cümlesine tesadüfle hayrette kaldım. Bir cümle-i kasîrede ne kadar hatâyâ-yı fahişe! Cüz’i bir müddet mektebe devam edenlerin cümlesi bilirler ki Araplar mülûk-ı Emeviye'nin evâili zuhurunda ve yedinci asr-ı miladide İspanya'yı ve biraz sonra Fransa'nın bir kısmını zapt ve istila ettiler ki bu vekayi'in cümlesi Sultan Mehmet-i Sani'den takriben yedi yüz sene mukaddem vuku bulmuştur.

Sultan Murad-ı Sani'nin oğlu olan Mehmet-i Sani ise Arap değil Türk idi. Hatta en evvel Avrupa'ya dâhil olan Türk hükümdarı bile o zat değildi. Çünkü kendisinden yüz sene evvel Sultan Orhan Bulgaristan ve Tırhala ve Yunanistan'ın bir kısmını istila etmiş idi. ${ }^{10}$ Görülüyor ki o muâhiz efendiler rastgele idare-i kelam ve hiç vâkıf olmadıkları bazı mesâilin muahezesine kıyam ederler imiş.

\footnotetext{
$9 \quad$ Volter'in Kâmus-ı Felsefe'sinden (dipnot metne aittir). Buradaki "Muaheze" baslı̆̆g ilk tefrikada Ebuzziya Tevfik Bey tarafından kaleme alınmıştır. Burada yapılan açıklamalar doğrudan Namık Kemal’in muahezesinin anlaşılmasına katkı sağladığından tefrikanın bütünlüğünü korumak ve kavramların o dönemdeki kullanım alanlarını daha iyi anlaşılmasını sağlamak için Ebuzziya Tevfik'e ait olan kısım da çalışmaya dâhil edilmiștir.

10 Volter de burada hata etmiştir. Çünkü dediği yerleri zapt eden Hüdavendigar-ı merhumdur. Sultan Orhan değil. (dipnot metne aittir)
} 
Bazı defa gazeteler rağbet-i âmmeden sukuta başladıklarını idrak eder etmez efkâr-ı umumiyeyi kendi taraflarına celp için bir mübahase açarlar.

Yine bazıları var ki bir eser-i nefis zuhuruna intizar ederler. Öyle bir eser mevki-i intişara çıkar çıkmaz hemen onu muaheze yolunda bir risale neşrederler. Duçâr-ı muaheze olan bir kitabın müellifi ne rütbe muteber ise muâhiz yazdığı risaleyi o nispette ziyade satar.

Hele iki veya üç kişinin ortaya bir bahis atarak badehu güya yek diğerine mukabele edercesine birtakım risaleler, kitaplar ve gazetelerde makaleler neşretmeleri ve bu eserlerinde ale'd-devam efkârıumumiyenin hükmüne müracaat etmeleri ne kadar açık bir eser-i tezvirdir. Zavallı efkâr-ı umumiye bilmez ki onlar kendi namına müteaddit hezeyan-nâmeler neşriyle celb-i menfaat için bir şirket teşkil etmişlerdir.

İntiha

Muahezât ve muahizîn hakkında Volter'in hülasa-i efkârı bâlâdaki ifadâttır ki güya müteveffa mezarından kalkıp İstanbul'a gelmiş de bazı müellefât üzerine muahezâtta bulunan erbab-ı ağrazın sîmâ-yı hakîkîlerini tasvir ediyormuş zannolunur. İhtimal ki muâhizler bu makaleyi kendi endazeleriyle ölçtükleri kâlâ-yı muhteri envaından kıyas ile Volter lisanından tasnî’ olunduğuna kâil olsunlar. Ne beis var. Onlar iktiza ederse hiçbir sâhib-i eserin lisanından sâdır olmadık ibareler tasnî̀iyle fikr-i tenkitkarânelerini o zemin üzerine bast ve irad ederler. Binaenaleyh biz muahezemizi makalenin bâlâsında irae eyledik.

Volter asrındaki muahizlerle bizim zamanımızdaki muahizlerin meslekçe farkları olup olmadığını ise Volter'in ifâdâttyla bunların efâl-i rûz-merrelerini mukayese edenler tayin edebilirler.

Galiba Cevdet Paşa Hazretleri'nin Belagat-nâme'lerinde görmüştüm. "Şâne-i zülf sühandâr-ı itiraz" yolunda ya zâde-i tabiatları yahut âhirin eser-i tab’ı olarak bir mısraı vardı. Hâyîde bir teşbihi havi olmakla beraber mahiyet-i itirazı pek güzel tasvir etmiş bir söz olmasından hatırda kalmış. Binaenaleyh itiraz sözün saçlarını tarayıp nizam verecek bir tarak hükmünde bulunur ise bir alet-i meşşâtât gibi daima erbabı için istimale salahiyeti münkir değildir. Fakat şâne denilen alet saçları taramaya bedel demet demet koparıp yolmakta veyahut nizam vereceğim diye taranan başa batırmakta kullanılır ise o hâlde lüzumuna değil mazarratına hüküm olunur.

İşte itiraz dahi lafza, manaya ve bir dereceye kadar fikre masruf olabilir ise de hiçbir vakit mahiyet-i eserle beraber tayin-i hakikat için kullanılan bir vasıta müessirin şahsına taalluk ettirilmemelidir. Çünkü bir sahib-i esere cahil demekten ise onun eserindeki cehli nezahet-kerâne bir lisan meydana koymak husul-i matluba kifayet eder. Yok itirazdan maksat bu mefhumdan hariç ve bizim anlayamadığımız etvârı nâtık ise ona diyeceğimiz yoktur. Edep dairesinde ve mücerret ait olduğu fenne ve müessirle beraber müntesibin edep ve irfana hizmet maksadıyla ise işte onun bir numunesini bundan on beş sene evvel Ekrem Bey Efendi'nin terceme etmiş oldukları bir esere yine bundan on sene mukaddem Kemal Beyefendi tarafından yazılan muaheze-nâmede gördüğümüzden yalnız tercümeye ait olan kısmını misal olmak üzere mecmuamızla ashab-ı mütalaaya arz eyledik: 


\title{
Me Prizon Tercümesi Üzerine Muaheze-i Kemâl
}

\author{
Kardeșim efendim
}

Me Prizon'u okudum. Sair eserlerinden aşağı buldum. Efkâr-ı ahrarânesi senin mertebende bulunanlar için doğru söz dokunaklı da olsa yine elbette müdâhaneden ziyade makbule geçer; onun için muahezeyi ibtidar ediyorum: Tarizatımın ekseri sana değil müellife aittir. Çünkü hemen bir dereceye kadar sergüzeştimin mirat-i in’itafı olan öyle bir eserin mevzuunu bir tarafa bırakıp da elfazıyla uğraşmaya gönlüm razi ${ }^{11}$ olmadı.

\section{Birinci Mebhas}

[12Acaba Silviyo hürriyet-i vatan namına irtibat hâsıl ettiği politika yolunda bir zindan-ı belaya düşmüş iken vicdanına nasıl galebe etmiş de mecruh-ı hançer-i zulmü olduğu maşukasına karşı sükût-ı edibane ile izhâr-ı infial eden âşık-ı sadık gibi politika yüzünden uğradığı felaketlere mukabil sükût ile teskin-i hararet teselli-i garibini ihtiyar eylemiş! Ne kadar mukteza-yı hâle mugâyir teşbih! Maşukasının siteminden şikâyet etmemek başka, aşk yolunda ağyar elinden çekilen felaketleri sükût ile geçmek yine başka. Bir vatanperverin vatanı için en şiddetli bir ıstırap içinde bulunduğu ve hususiyle vatanını kendinden mustarip bir hâlde gördüğü zaman hissedeceği teessürlerden daha ulvi, daha şâirâne, daha hazin acaba dünyada bir şey var mıdır? Hazinetü'l-gayb-ı efkârın en kıymetli cevheri, mekârimpesendân-ı insaniyetin en sevgili maşuku denilmeye layık olan öyle birtakım ruha kuvvet verecek ve insanın sahihen insan olmasına hizmet edecek tasavvurları adem-âbâd-ı sükût içinde mahvedip geçivermeye bir edip nasıl kıyabilir? Mahbes müdürlüğüyle meyhaneciliği cem' etmekte iblise hayretbahş olacak bir maharet-i hasise gösteren edânîden bahsedip de can almakta, hanüman yıkmakta Azrail'e rekabet edecek kadar dehşet izhar eden zalemeyi lisana almamak şâirâne bir meslek midir? Ben onun yerinde olsam, velev ne kadar maskara olursa olsun, insan kisvesine bürünmüş bir şeytan tarif etmekten; velev ne kadar hâil görünürse görünsün, insan şekline temessül etmiş bir melekü’l-mevt tasavvur etmeyi bin kat müreccah görürdüm. Silvio'nun netice-i mebhasta yazdığı ağlamak zaafını da doğrusu beğenmedim. Çünkü vicdanıma tatbik ediyorum; hubb-ı vatan kadar mukaddes bir maksat kalbe gerçekten yerleşince kendine mukabil gelecek hiçbir hisse yer bırakmamak lazım gelecek. "Ya gönül kabil-i taksim idi, ya bir değil bende gönül üç beş idi” hayâl-i şâirânesi hevesât-ı şebaba bir güzel hülasadır.

Fakat gönül hakikaten münkasım veyahut müteaddid olmadıkça bir kere vatan hissinin istilasına düştükten sonra içinde başka bir hâkimin istibdadına imkân kalamaz. Cumhurda padişah olamadığı gibi... Ne hacet ikimizce de mücerreb olan hâller davamı ispata kâfidir. Avrupa'ya gittiğim sırada ben de ailemden ayrıldım, hatta müteehhil idim. Hatta bir de hayatımdan kıymetli bir kızım vardı. Ve hatta başımda dünyada en şiddetlilerinden bir sevda da mevcut idi. Cümlesine mütehassir gittim. En sonraki mülakatım da seninle idi. Gözümde bir damla yaş yahut rengimde bir tagayyür gördün mü? Hiç fedakârlık gibi merdânegî-i mücessem vasfina dünyada her şeyden ziyade layık olan bir hiss-i âlînin mahkûmu olanların gözünde tıflane bir feryad-ı bî-sadadan ibaret olan girye nereden hâsıl olur? Avrupa'da Silvio'nun şikâyet ettiği hasretlerin umumuna maziyadeten müptela idim. Gönlüme hiçbir vakit rikkat bile gelmedi. Yalnız bir kere az kaldı sevda getirecektim. Ona sebep de kendi hâlim değil,

Bu ifade ikinci nüshada "kâil" şeklindedir.

Namık Kemal'in Me Prizon Muahezenâmesi, Mecmua-i Ebuzziya'da iki kez tefrika edilmiştir. İlk tefrika daha ziyade eserin tercümesine yönelikken ikinci tefrika Ebuzziya Tevfik'in ifadesiyle "hâl-i asliyesi"ni ihtiva etmektedir. Her iki tefrikayı birbirinden ayırmak için ilk tefrikada olmayan ancak ikinci tefrikada olan kısımlar köşeli parantez ([]) ile göstermeyi tercih ettik. Bununla birlikte iki nüsha arasındaki farklı kullanımları da dipnotta gösterdik. 
tervic-i maksatta fırkanın gösterdiği zaafla münasebetsizliklerdi. Hubb-ı vatanın galebe-i mutlakasına şimdiki hâlimde o kadar deliller gördüm ki mesele indimde adeta bedîhiyet kuvvetini buldu, diyebilirim. Hasret-i akraba ve ehibbadan başka bir de sebepsiz, muhakemesiz diri bir kabristana atılmak tasavvuru göz önüne alınsın. Zannederim ki kalbi iz'af etmedikçe bu hâl Silvio'nun felaketinden birkaç kat şiddetlidir.

Mamafih insan maksadını severse maşukası gibi cefasıyla beraber belki cefası için seviyor. Binaenaleyh ağlamak, teessür etmek şöyle dursun, uğradığım musibet bana adeta bir eğlence zamanı gibi geliyor. Tevkif olunup da Hapishane-i Umumi'ye gönderildiğim gün memurlara selamdan sonra en evvel söylediğim "Efendilerimiz bizi buraya hapsedeceklerini bilmişler de eğlencesiz bırakmamak için ön tarafa bir de bahçe yapmışlar.” sözü olmuştu.

Hele arkadaşlarla vapura giderken maksad-ı celilin hissiyat-ı kutsiyesi hâlimize bir derece ulviyet vermişti ki hakâyık-ı mücerredeyi şuhûda muktedir bir nazarla yürüyüşümüze bakılsaydı hubb-ı câh, hırs-ı ikbâl, meyl-i tehakküm gibi zelîl iken âlî görünmekte şaha kalkmış yılandan hiç farkı olmayan deniyyât-ı alâyık ayaklarımızın altında bir mezellet-i hakîkiyye ile hâksâr olmuş görünürdü. Herkesin sükût-ı laubaliyane ve mekânet-i vakuranesi

\section{Müberrâyım recâ vü havfdan indimde âlîdir}

\section{Vazîfem menfaatten, hakkım ağrâz-ı hükûmetten}

beytinin mealine misal-i müşahhas olmuştu. Hele birinden birine naklederek buraya geldiğimiz üç vapurda zevkimiz, safamız, sürurumuz, şetâretimiz bir derecede idi ki o kadar huzur-ı kalp ile geçirdiğim eyyamı ömrümde pek az biliyorum. Hatta sevkimize memur olan ve sevkimize dikkat edenlerden biri bir gün beni tenha bularak "hâlinize baktıkça nefye adam götürmüyorum, nefiyden vatana adam getiriyorum itikadına düşeceğim" demiş ve bizim taraftan "vatan için her ne çekersek vatanımız kadar severiz” cevabını almıştı. Geceleri Silistre’nin şarkılarını okurdum. Yüreğimde hissiyat o kadar büyür ve o kuvvetle evzâım o kadar müessir olurdu ki dinleyenleri sahihen Silistre gibi muhasara hâline düşmüş ve müdafaa-yı vatanperveranesini hadd-i imkândan çıaracak raddelere götürmüş bir bedbaht kale karşısına tesadüf etmiş gibi gayet dehşetli bir beht-i gazûbâne ile mümteziç gayet tesirli bir şefkat-i mütehayyirane istila ederdi. Rodos'ta arkadaşlardan ayrıldık. Uhuvvet-i efkâr ve hususiyle karâbet-i mesâibden dolayı mülâsı doğmuş tev'emlerin iftirakı derecesinde ıstırap çekmek lazım gelirken kimsenin rengi bile tahavvül etmedi. Güya ki meclis-i ülfet hitama ermiş ve gidenler ertesi günü yine bir yere gelmek üzere hanesine gitmek için ayrılmıştı. Yalnız esna-yı seyahatte bir eser-i infial gördüm. $\mathrm{O}$ da Hakkı'nın ben Kıbrıs'a çıkarken bir savt-ı hazin ile Kemal, senden ayrılacağıma canımdan ayrılsaydım yolunda bir söz söylemesidir ki sırf muhabbet-i halisâneden dolayı biçarenin kalbinden koparcasına ihtiyarsızlıkla ağzından dökülmüş olan şu birkaç lakırdı bile gerek ben gerek Nuri'de tahrik-i hiddetten başka bir tesir hâsıl edemedi. Zavallıyı en masumane bir his için adeta tekdir ettik. Ne demek birader, hiç insan Silvio gibi yahut bizim gibi bir iptilaya uğrayınca vatanına cüzi ve külli edebileceği hizmetten mahrum olduğunu bile düşünmeksizin valide veyahut pederinden ayrıldığına ağlar da kendini insan bilirken ihtiyarıyle çocukluk hâline tenezzül eder mi? Hiç adam on on beş sene her türlü hevesat ve temayülatına galebe ederek vücudunu vatanına, milletine vakfetmeye muktedir olup da ondan sonra bir felakete düşerse sevabıkının mefhareti ve hiç olmazsa vazifesine ittiba' etmek bir bir medâr-ı teselliyeti var iken o kadar güzel o kadar âlî hayalâtı pîş-i nazarından girye-i aczle mahveder mi? Avrupa'da bulunduğum müddet meslek-perverlik sâikasıyla pek çok politika mültecisiyle görüşmüş ve yine o yolda zindanlara atılmış pek çok mahbus görmüştüm. İçlerinde kadınlar, çocuklar, aç kalanlar, bin türlü eziyet 
çekenler vardı. Hiçbirinin gözünden yaş değil, lisanından bir harf-i şikâyet hâsıl olmazdı. Tarihler, gazeteler meydanda duruyor. Yunan'ın, Roma'nın, Arap'ın, Türk'ün, İngiltere'nin, Fransa'nın, Amerika'nın, Almanya'nın, İspanya'nın ve hatta Garibaldiler gibi hadîd-i metanetten dökülmüss nice timsal-i hürriyet numune yetiştiren İtalya'nın eshâb-ı inkılabâtına dair yazılan tafsilat arasında hiç teessürle ağlar göz, korkuyla çırpınır gönül tarifine tesadüf olunur mu? Zaman-ı felakette ağlamak hazzı nefs veya hırs-ı câh ile siyaset dairesine girenlere yakışır.

Şüheda-yı hürriyetin giryesi yaralarından dökülen hûn-ı nâ-haktır. Hubb-ı vatan dedikleri timsâl-i ruhanîye meftuniyetle mecruhü’l-fuâd olanların vakt-i iptilada gözlerinden yaş değil ateş saçılır.

Muahezede bu kadar uzun lakırdılar söyleyişim memleketimizde henüz yetişmekte olan hubb-ı vatan arasında Avrupa inkılap taraftarânından en acizinin kendi itirafıyla müspet olan tercüme-i hâlini meydana koymaktan efkâr-ı milliyece bir hayli su-i tesirler hâsıl olabileceğini layıkıyla ispat içindir.]

Tercümenin şive-i ifadesi şimdiki âsârından aşağıdır. Vakıa bu faslı bizim lisana naklettiğin zaman senin kuvve-i kalemin değil hatta milletin edebiyatı şimdiki âsârında görülen mertebe-i istikmâle vâsıl olamamıştı. Şu kadar var ki eserini tashih edebilirdin. Mesela "aks-i endâz" ve "akamet-sâz" kafiyesi gibi eskimiş veyahut "âvihte-i şecere-i ibret" gibi hüsn-i münasebetten ârî sözlerin pek kolay ıslahı kabil idi sanırım. Bir de "Hey gidi saat... Hey gibi ahval..." terkiplerindeki "gidi" lafzına ilişiyorum. Benim bildiğime göre gidi¹3 Türkçede “...onun”14 manasına olarak mesela "domuz herif” ve "köpek oğlu”, "boktan şey” tabirleri gibi galatât-ı avam ile mana-yı mevzuundan çıkarılmış ve makam-ı taaccüpte zebanzet olmuştur. Mamafih galatât-ı avamın istimaline kat'a tariz etmemekle beraber bu yolda müstehcen tabirlerin edibane yazılmış bir eserde bulunmasında cevaz tasavvur edemem. Hususa ki münasebet-i makam dahi gerek zamanın ve gerek cihanın, öyle tahkirli bir sözle tavsifine lüzum göstermiyor. Zamanda sürat-i güzerânın, cihanda kesret-i inkılabın vücudu neden ikisinin de hicvini iktiza etsin.

\section{İkinci Mebhas}

[Bunun meali de müellifin hubb-ı ailede olan şiddetiyle vatan muhabbeti yolunda çekdiği felaketten bîzarlığını gösterir birtakım hissiyat-ı hasîseden ibarettir. Zannederim ki vatan Silvio'yu kendi hizmetine zûr veya hile ile davet etmemiştir. Acaba bu zat inkılap firkaları arasına karıştığı vakit sonundaki muhataraları düşünmemiş mi? Düşündüyse o kadar rakik olan kalbine evvela nasıl galebe etmiş de ashâb-ı hamiyet arasına atılmış. Sonra niçin galebe etmiş de babasını, anasını düşünerek ağlamamış! Evet hubb-ı aile de bir hiss-i mukaddestir. Fakat hubb-1 vatana galip tutulmak lazım gelmez. Nitekim sehâvetin tarif-i diğeri olan muhabbet-i fukara da memduh bir histir. Lakin hubb-1 aileye takdim olunmak iktiza etmez. Hizmet-i vatan yolunda felakete uğramış bir gayurun aile hasretiyle ağlaması ailesini zaruretten kurtarmak için malını telef etmiş bir sahînin tasadduk hasretiyle girye-bâr olmasına benzer. Ben de Avrupa'ya giderken pederimden, ailemden ayrıldım. Fakat hatta ayrılacağım saatte dahi gözüme vatanın harita-i azametinden başka bir şey görünmez, fikrime vatanın sevâbık-ı fâhiresinden başka bir şey hutûr etmez, gönlüme vatanın ikbâl-i istikbalinden başka bir his tahakküm eylemezdi. Aile muhabbeti dahi hissiyat-ı ulviyesinin eczasından biri olan koskoca vatanımdan yine vatanım için ayrıldığıma ağlamayacağım da ailemden ayrıldığıma mı ağlayacağım?]

\footnotetext{
13 [Gidi kelimesi, kuvvetini artırmak üzere hatta bazı sıfatlarda ilave olunarak Anadolu'nun birçok yerlerinde hala mana-yı asliyesinde sövüp saymak için kullanılmaktadır. Bu sebeple her nasılsa İstanbulluların makam-ı taaccüpte dillerinde tedavülü itiyat edindikleri bu kelimenin istimalinden tevki edilmek lazım gelir.] (dipnot metne aittir) 
$\mathrm{Bu}$ mebhasın tercümesini de birinci mebhasın tercümesinden kuvvetli bulmadım. Doğrusu ben şimdi “tevcih-i dürbin-nazar" gibi "dü-dide-i hicrân” ve "didemi eşk-rîz-i tessür” gibi vaz'-ı leb dehan-ı tehassür” gibi tatsız teşbihli, hâyîde cinasl, lüzumsuz kafiyeli sözleri sevemiyorum. Akraba ve aile gibi maruf kelimeler dururken şimdiki edebiyatça adeta elfâz-ı garîbeden ma’dud olan "havişan" tabirini kullanmakta mana nedir? Edebiyatımızda mümkün oldukça Farisî şive ve tabirlerini azaltacak değil miydik? Hele "tündâde-i câme-hâb oldum" terkibi velev aynen tercüme bile olsa "yatağıma yattım" veyahut "vücudumu yatağa attım" terkiplerinin burada biri kadar olamaz. "Hazz ve mesar" gibi atf-1 tefsirleri pek çok kullanıyorsun! Bazı kere bu nakîsa kafiye-perverlikten geliyor. Halbuki kafiye-perverlik maksadını yalnız matufî kullanmak dahi istihsal eder. Bazı kere kafiye-perverlik mütalaasından berî olarak yine ekserinde atıf tefsiri bulunuyor. Sebep su-i meleke ise ondan geçmenin bir çaresine bakılmak lazım gelir. Yok mürekkebin ziyade olup da hokkanın süratle boşalmasını murat ettinse bari birazını fukaraya tasadduk et.

\section{Üçüncü Mebhas}

[Silvio'nun mahpus iken ilk gece uykudan uyanmakta olan dehşet hakkındaki hissini de vicdanıma tatbik ettim; doğru bulmadım. Ben Hapishâne-i Umumi'ye ilk gittiğim gece on saatten ziyade uyku uyudum. Sabahleyin dahi bizim evde yattığım gecelerin ekserinden daha sakin, daha rahat kalkmıştım. Her şeyden evvel zihnime arkadaşlarımın hâli geldi. Çünkü onların da tevkif olunduklarını geceden işitmiştim. Memurların birinden sordum. Odadan çıktı, biraz dolaştıktan sonra geldi. Yalnız Mithat'ın uyanık olduğunu ve küsurlarının benim gibi saat üçte yatağa yattıklarını ve aradan on bir buçuk saat geçtiği hâlde yine rahat uyumakta olduklarını haber verdi.

Hatta kendi zarifçe bir adam olduğundan gülerek "Galiba sizin kabahatiniz, millete lazım olan vücudunuzu uykusuzlukla harap etmekmiş de buraya sizi rahat etmeye göndermişler” demişti. Ben de ona mukabil: "Öyle olmak gerek. Hatta ben Paris'te iken meşhur Rochfort'u hapsettiler; ahbabı ise, biçare, şimdiye kadar vatanına hizmet için gecede ancak iki saat uyku uyurdu. Mahbeste bir müddet olsun rahat eder de vücuduna biraz sıhhat gelir diye söylenmişlerdi” cevabını verdim. Hapishane-i Umumi şöyle dursun Magosa'da bile gönlüme öyle ilk gece korku yollu vehmiyyât-ı tıflâne hutûr etmemişti. Bizim ilk gece ise hubb-ı vatan kuvvetiyle mücehhez olmayan bir kalbe gerçekten dehşet verebilecek hâllerden idi. Bazı yerlerini tarif edeyim de bak.

Kıbrıs iskelesine takriben saat dörtte çıkmıştım. Hükümet konağında yemek yedik. Saat altı raddelerinde bir zaptiye yüzbaşısı, dört zaptiye, iki topçu neferi önümü arkamı sarmış olduğu hâlde yola girdik. Magosa'ya yarım saat kala güneş gurûb eyledi. Buranın mağribi dağlar, dumanlar içinde bulunduğundan şafağın bin türlü zulmânî renkler içinde görünüşü o kadar sevdâvî idi ki eğer Küçüksu'da şevk ve muhabbet âleminde öyle bir guruba tesadüf edeydim bî-ihtiyar saatlerce ağlardım. Bulunduğum hâlde ise nazarıma çarpan temâşâ-yı hazin gönlüme tesir etmedi. Zihnimde hâsıl olan mütâlaa âdeta işte güneş batıyor; yarın yine doğar, fikr-i âmiyânesinden ibaret idi.

Akşam pek karanlık değil ve fakat sisler, puslar içinde ve bayağı ağlar gibi hazin bir hâlde idi. Ondan da katiyen müteessir olmadım. Yolda gelirken hikmet-i tabiiye meraklısı bir adam gibi, o sisleri, pusları peyda eden buharın suret-i suûdunu ve derece-i gılzet ve hiffetini düşünürdüm.

Kaleye yaklaşınca, dembedem tezayüt etmekte olan karanlıkla imtizaç etmiş gayet hafif ve açık mâiye mâil bir bulut arasından gözüme bir kabristan ve içinde oldukça büyük bir kubbe görünmeye başladı. Yanımda bulunanların birine kubbeyi sordum. Atpazarı Şeyhi Osman Efendi merhumun merkadi 
olduğundan tutturarak burada kalebent iken irtihal eylediğini söyledikten sonra gayet masumane ve her türlü su-i niyetlerden berî tarz-ı sade-dilane ile Magosa'nın vahâmet-i havasını ve buraya menfiyen gelip vefat eden bir yirmi kişinin kısacık tercümeihalini anlattı. Mezarların nerelerde bulunduğunu tarif etti. Ve hatta birtakımının bünyeleri fevkal-gaye kavi iken bir iki defa sitma tutuvermekle irtihal ettiklerini de ilavede kusur eylemedi.

Sohbet buraya eriştiği sırada biz de türbe ve kabristan kenarına vasıl olduk. Yek-nazarda mezarlık, gözüme her insan için münteha-yı istikbal olan mevt-i hâilin topraktan yapılmış bir timsali gibi göründü. Yine fikrimde, dünyanın neresinde hava mühlik değil ki burada olmasın? Birkaç yll evvel veya birkaç yıl sonra ölmenin ne hükmü olabilir ki insan ne vakit öleceğini düşünsün, mütalaalarından başka bir şey cevelan etmez ve lisanımda hakikaten mütecellidane bir tarz ile "altı da bir, üstü de birdir yerin" mısraını tekerrür eder dururdu. Bizim refik-i râh ise bendeki sükuneti gördükçe sözlerinin başka türlü tesir edeceğini hiç hatırına getirmeyerek lâyenkati’ herze-vekilliğinde devam ederdi. $O$ hâl ile Magosa kapısına eriştik. Bir eski tahta köprüden geçtik, kasabaya dâhil olduk. Burası metruk kabristanlar gibi yalnız yıkık, çürük, taş yığıntısından ibaret bir harebe-zârdır. Hane suretinde olan mahallerin deliğinden deşiğinden çıkan ve fakr ve mezellet cihetiyle vücutlarında kuru kemikten ve çehrelerinde çürük deriden başka bir şey kalmamış olan yarı çıplak sekenesi göz önüne alınınca, bayağı, kefenleriyle mahşer meydanına uğramış emvât kıyas olunur. Zaman-ı vusulümde ise gecenin zulmeti bu dehşet-abâda nisyan-ı ebedî kadar korkunç libâs-ı mâtem kadar hazin bir perde-i siyah çekmişti. Birkaç dakika bu zlâl-i ahvâl arasında her adımda bir taşa ve her köşede birkaç mûziyâta tesadüf etmeksizin geçmesi muhal olan zevkıyet ve inhirafta en mühim sıçan yollarına meydan okuyan sokak veya tabir-i sahihle girizgâhlardan geçerek hükümet konağına vasıl oldum. Mülkiye kaymakamı ile asker yüzbaşısının çehreleri akrabasının idamına memur olmuş bir hizmetkârı andırırcasına veleh ve dehşet içinde idi. Meğer vapurda iken menfamız Lefkoşa'dan bir telgrafla Magosa'ya tahvil olunduğu gibi bir diğer telgraf ile de tevkif-i askerî tahtına verilmişiz.

Lefkoşa'da bulunan kaymakam ise kemal-i dirayetinden "tevkif-i askerî" kelimesinin manasını bir garip yolda anlayarak asker neferâtının hapis olunduğu yerde tevkifime emir vermiş. Halbuki benden evvel buraya menfiyen gelen Emin Bey kalenin haricinden dâhiline nakil olunmakla nüzul getirecek derecede havf ve telaş gösterdiğinden berikiler katiplik karinesiyle beni de ona kıyas ederek korkudan helakimi tevehhüm etmişler. Etvâr-ı mütehayyiranelerine sebep o imiş! Hükümetten kışlaya geldik. Mülazım, askeri meydana dizmiş, divan vermekte idi. Merdiven başına yaklaştık. Kaymakam hemen firladı, yukarı çıktı. Yüzbaşıya "Biz nereye gideceğiz?” dedim. "Hasbe'l-icap şimdilik buraya!" cevabını aldım. Gösterdiği yer, kışlanın iki dirseği arasında yapılmış bir zemin ile beraber bir oda idi ki arz ve tûlü birer karış olmak üzere tahta ile mesdûd bir penceresi, bir de eğilmeden girilmesi muhal bir kapısı var idi. İçine girdim. Kenarında taş dirseği üzerine yorgana benzer bir şilte serdiler. Bir tarafına çarşaf inceliğinde bir yorgan, bir tarafına şilte kalınlığında bir yastık koydular. Kapının önüne de tüfekli iki karakol diktiler.

Dünyada en hafif vehimle muttasıf bir adam öyle bir hâlde bulunsa, mutlak idam olunacağına zâhib olurdu. Ben ise câme-hâb-ı huzur üzerine uzandım. Baktım ki odamın tûlü tamam boyuma göre yapılmış, her taraf toprak. Bir cihetinde iğne deliği kadar menfez yok. Adeta yer yüzünde yapılmış bir lahit içindeyim. Bu hâlde zihnimden ne geçse beğenirsin? Vapurda iken Âkif'in tertibini tasavvur etmiştim. Fakat tasavvurumca Dilrüba'yı kâh Âkife kâh Pertev'e idam ettirmek ister ve bu suretlerin hiçbirini beğenmezdim. O vahşet-âbâd içinde uyumanın zihnen olsun itmamına çare düşünmeye başladım. Süleyman Kaptan’ı o sırada ihtira ettim. Ben o telif-i zihnî ile meşgul iken önüme iki sahan yemek getirdiler. Safa-yı hâtırla yedim. Zaman-ı hazmı bile beklemeksizin hemen uykuya yattım. O gece 
on bir saat kadar uyumuşum. Birkaç kere kaldırmaya geldiler. Gelenleri defettim. Biraz daha uyudum. Yine bizim evdeki uykulardan rahat uyandım. Zabitler sükûnet-i hâlime bakmışlar da bey-i hâl ya firarıma yahut itlâka mutmain olduğuma zâib olmuşlar. Sabahleyin kışlada benim için başka bir oda hazırlamışlar, oraya çıkardılar. Müddet-i medîde memurlarla eğlendim ve hatta mizacımın hilafına olarak birkaç kere istihza ettim. Niçin ağlayacağım? Niçin ailemi filanı tahattur ederek müteessif olacağım ki ben zaten girdiğim mesleğe her muhatarasını düşünerek, her belasını göze alarak girmiştim.

Hele Silvio’nun hapse girdikten sonra o kadar dindarlığa dökülüşü bir nevi iman-ı ye’is hükmünde olduğundan letafet ve ulviyet levâzım-ı zarûriyesinden olan hayâlât-ı şâirâne dairesine uğrar şeylerden değildir.] Bu mebhasın tercümesini de evvelkilerden farklı bulamadım. Bir "istifham-ı ma'al-inkâr" terkibi icat etmişsek, "istifham-i inkârı̂" ıstılah-ı ma'rufu meydanda dururken ona hiç lüzum yoktu zannederim. Mehbasta olan münasebetli münasebetsiz yaygın yaygın kafiyeler için tekrîr-i itiraza hacet ${ }^{15}$ göremem.

\section{Dördüncü ve Beşinci Mebhaslar}

Müellif dördüncü mebhası pek güzel, pek tabii bir hâlde tasvir etmiş. Tercüme de zararsız. Lakin yine kafiye-perverlik nakîsasından hâlî değil. Beşinci mebhasın da suret-i tertibine diyeceğim yok. Tercümesi de birkaç ıstılah ve bir iki kafiye lekesinden berî olmamakla beraber takdire şayan. [Bence ise mütalaasından iki garip fikir hasıl oldu: Silvio ne bahtiyar imiş ki zindan-ı iptilada istintaklar geçirmiş. Beni de ne olurdu biri yanına çağırıp da "Karnarsi" diyeydi. Zannetme ki istintak medâr-ı tahlis olur zannıyla bu kadar hasret çekiyorum. Pek âlâ biliyorum ki bir adamın muhakemesiz nefyinden içtinap etmeyenler istintak altına alındıktan sonra tagribinden betarîkü’l-evla çekinmezler. Yalnız istintak veya muhakemeye çağırılmış olsaydım gerçekten vatanını seven bir adam, zalemeyi ne sıfatta görüyormuş ve mesleği için uğradığı teaddiye ne dereceye kadar ehemmiyet veriyormuş; şunları göstermek isterdim. İnsan İslam uğruna nasıl feda-yı can etmez ki muhafazama memur olan mülkiye ve askerî takımı üç dört defadır değişiyor. Gidenlerin, gelenlerin kâffesi vatan ve millet uğrunda ${ }^{16}$ bu musibete uğradığımı bildiklerinden hakkımda akrabamdan, ahbabımdan ziyade hürmet ve insaniyet gösterdiler. Bunlarla Silvio'nun müekkilleri beyninde görülen fark, İslamiyet’in fezâil-i ahlakı netayicinden değildir de nedir?

Yaşa ey millet-i sâhib-i saadet

Senin sâyendedir bu feyz ve izzet

\section{Altıncı, Yedinci, Sekizinci Mebhaslar}

[Altıncı mebhas yine müellifin zaaf-ı kalbinden peyda olma bir inkârdan ibaret. Mübarek elinde o kadar kitap varmış da ne gariptir ki okumaya nefsinde iktidar bulamazmış. Ben ise buraya geldiğim zaman mutasarrıfa yazdıkları istizanın cevabı gelinceye kadar yazı yazmaktan mahrum bulunduğumdan yanımda bulunan Ravzatü's-safa'yı odamda tenha kaldıkça elimden hiç düşürmezdim. Zihnimde mütalaa ettiğim yerlerin manasını bence bir şeyin manasını ne kadar suhuletle anlamak mümkün ise o kadar suhuletle anlardı.]

Bu bahsin tercümesi dördüncü ve beşinci mebhaslardan aşağı. Yedinci mebhas edebiyat nokta-i nazarında ikiye taksim olunmak lazım gelir itikadındayım. Bunun birincisi mebhasın mebadisinden

\footnotetext{
15 Bu ifade ikinci nüshada "lüzum” şeklinde geçmektedir.

16 [Zavall Kemal burada kendi kendini aldatıyor. Bizim o seferki tagayyürümüz vatan ve millet yolunda bir hareket neticesi miydi? Bir müfteri-i menfaat-perestin tahrik-i evham için ihtira ettiği bir yalana kurban olmak ile "vatan ve millet" hizmeti arasında ne münasebet mutasavverdir?] (dipnot metne aittir)
} 
bence kitabın en zayıf yeri görünür; çünkü içinde tenakuz var. Müellif eserinin bir fikrasında kendi hâli için "sırf bir tevekkül-i ıztırarî eseri değildir" diyor. Bir diğer yerinde ise "tali'-i vajgun beni uzun uzadıya ber-kayd-ı esarete giriftar veyahut pençe-i suhtegir-dârde zâr-nizâr etmekle tecelli-nümûn olacaktır. Artık bunda tevekkül bihakkın iktiza eyledi." fıkrasını îrâd eyliyor. Malumdur ki ıztırar bihakkın sözüyle ifade olunmakla mahiyetini değiştirmez. Silvio'ya öyle bir hâlde tevekkül ne yapacaktı? Mahbesin kapılarını (mı) kıracaktı, kaderin pençesini mi bükecekti? Bu tevekkül veya teslimiyet ki bela geldikten sonra vuku bulur bir suretle ihtiyarî hükmünü alamaz. Bu cihetin tercümesini de pek zayıf buldum. İfadâtına şive-i Acem galebe etmiş. Bir de zannederim ki tevekkül yerine teslimiyet kullansaydın ifade daha vazih olurdu.

Mebhasın ikinci fıkrası ki dilsiz çocuğa dair olan fikrasıdır. Fevkalade bir felaket içinde bulunan bir şaire kudretin hiç umulmadık yerden ihsan ettiği bir zevk-i vicdanîyi pek şâirâne bir tarzda tasvir eylediğinden kitabın en güzel yazılmış yeridir diyebilirim. Tercümesini de aslına mutabık buldum. Hatta kafiyeleri, ıstılahları bile güzel. Buraya vürûd ettiğim sıralarda benim de en evvelki ahbabım dört yaşında bir çocuk idi. Kendi dilsiz değil ise de gayet terbiyesiz ve bununla beraber gayet zeki bir şey ${ }^{17}$ olduğundan evzanda gördüğüm garip garip haller, insanın tabiatına bırakılsa ne mizaçta bir hayvan olacağına dair zihnimde birçok hayalat-ı hakîmâne tevlit eyledi ki onların tafsilatı Magosa ${ }^{18}$ sergüzeştine dair derdest olan telife yazılırsa hayli mühim bir mebhas olur. Fakat onu ayrıca bir hikâye veya tiyatro suretinde yazmak istiyorum. Bakalım gönül hangisine karar verecek.

Kitabın sekizinci fikrası da bir kalb-i safın teşrihinden ve birtakım hissiyat-ı insaniyet-kâranenin tahlilinden ibaret olmakla letafette birinci fikranın cihet-i saniyesine hemen yaklaşıyor. Fakat tercümesi yukarısı kadar güzel değil.

\section{Dokuzuncu, Onuncu, On Birinci Mebhaslar}

[Silvio dokuzuncu mebhasta bütün bütün reculiyetten sükûtuna hüküm olunabilecek derecelerde zaaf-1 kalp göstermiş; bir mahbesin bir odasından diğer odasına naklolunmakla o kadar telaşa ne lüzum vardı? Demek ki bu zat her alıştığından ayrıldıkça ölüm azabına uğramış kadar müteessir olacak! Odanın duvarındaki "lanet ve melamet o korkaklara ki hapis ve felaket kendilerini dindar eder" ibaresi, vakıa küfr-i mahzdır. Fakat zaman-ı asayiş ve saadette umûr-ı diniyesini düşünmeyip de bir felakete uğradığı gibi hani din derler bir şey var idi, bir de oraya müracaat edeyim; belki necatıma vesile olur, diyerek diyanetle tecrübe-i tali’e kalkışmak da dinsizlikten aşağı kalır denaetlerden değildir.]

Bahsin tercümesi ehven ve fakat içinde "bizden başka bir yabancı" ibaresine tesadüf ettim. Hem "başka" hem "yabancı" tabirleri bir yerde nasıl içtima eder? Bir türlü anlayamadım. [Onuncu mebhas, bir vatanpervere layık olan lisan-ı metaneti andırır yoldadır.

Lakin] tercümesi yine ıstılaha boğulmuş. On birinci mebhas pek şâirâne, eğer içinde bir münasebetsizlik olmasa. Şairane dediğim bahsin mevzuudur. Ya şair bila-1ztırar bir âlem-i tenhayi içinde ömür geçirmeye mecbur olmuş olduğu ve o hâlde vazife gibi, endişe-i akıbet gibi, hasret gibi, beyin yakmaktan, gönül paralamaktan başka bir tesiri olmayan hissiyat-ı şedîdeden başka düşünecek bir şey bulamadı̆̆ı hâlde yalnız sesini işitmek ve belki de ara sıra hayal-i saadet gibi gözünün önünden güzerân-ı ser’ini

\footnotetext{
17 "Bir şey" ifadesi ikinci nüshada bulunmamaktadır.

18 İlk nüshada “......” şeklinde olan bu ifade ikinci nüshada "Magosa” olarak yazılmıştır. Anlam bütünlüğü açısından ikinci nüshadaki kullanımı tercih ettik.
} 
görmekle bir kıza ismet-kârane alaka-bend olmak hayali dünyada en ziyade hissiyat-ı kalbiyeyi okşayacak lezaiz-i ruhaniyedendir.

Silvio ise bu hâlin tarifinde pek büyük bir maharet-i edibane göstermiş. Münasebetsiz dediğim de Silvio'nun penceresi önünden geçen mahpuslara bir muhabbet-i insaniyet ve hizmetkâr-ı vatana layık olduğu üzere şefkatle müteessir olup dururken ona da alışıvermesidir ki hâlinde görülen bu tebeddül hissiyatının sebattan ârî ve tabiatının iyilikten, fenalıktan her şeyle pek kolay ülfet hâsıl etmeye kâbil olduğunu gösterir. Bu mebhasın tercümesi de ıstılah-perverlik seyyiesinden kurtulamamış.

\section{On İkinci, On Üçüncü, On Dördüncü Mebhaslar}

On ikinci mebhasın mukaddimesinde müellif yine sekiderek insaniyet muhabbeti namına girdiği bir mesleğin neticesinde bir felakete uğramakla insaniyete düşman olmak gibi bir hiss-i denî kalbine istila edermiş. Gariptir ki nice yüz bin mazlumun enîn-i ıztırabını düşünmek kalbinden bu türlü infiâlât-ı hasisenin define medar olamazmış da sükûnet için bir kızın nagamâtına arz-ı iftikâr edermiş! Müellifin oda komşularıyla olan muhaveresi güzel bir ahlak dersidir.

Mebhasın tercümesini yine beğenmedim. "Darü’n-nedve” tabiri makamında düşmemiş; çünkü darü’nnedve tabirât-ı hicviyeden ise de istimal olunduğu mahal, meşveret-gâh olmak şarttır. Mahbes falan gibi mahallerde kullanılamaz sanırım.

On üçüncü mebhas da gerek ahlak ve gerek edebiyatça kitabın en güzel parçalarından biridir. Hele müellif gerek mahpusların ve gerek mahpes müvekkillerinin tasvir-i hasâilinde en ziyade göze çarpacak bir rık'a ihtiyar etmiş. Hak tarafından tercümede meselenin sadeliğine muvafık düştüğünden mebhas, lisanımızda yapılabilecek bir müntehibat mecmuasına derc olunmaya şayan olan âsâr-ı ber-güzîdeden add olunsa şayestedir. Bayağı heyet-i umumiyesi itibariyle dilsiz çocuk ve Madlen fikralarına tercih olunabilir.

On dördüncü mebhasta Silvio, yine mutadı olan zaaf-ı kalbe şiddetle mağlup olmuş. Fakat pederiyle mülakatında nakleylediği ifrat-ı teessür bu yolda tecârübden berî olanlara göre tabii ve en meşru görünür. [Fakat siyaset kavgalarında böyle bir hâlin delalet ettiği his, şefkat-i sahihe değil zafiyet-i acizanedir. Ben de hapsolundum. Nefye gelirken pederimle görüştüm. Yanına gittiğim zaman ne gönlümde ketmedecek teessür ne de gözümde saklayacak yaş vardı. Hatta pederim ağlayacak oldu. Gösterdiğim metanetin dehşetinden gözlerine gelen yaş korkmuş da geri çekilmiş gibi birdenbire gaybubet eyledi.] Yine tekrar ederim bir gönülde teessürat-1 acizane ile hubb-1 vatan ittihat etmez. Bu mebhasın tercümesini de beğenmedim. Bilmem isteyerek mi yaptın, yoksa tabiat-ı şâirâne ve hissiyat icbarıyla mıdır? Ekseriyet üzere tercümenin güzelliği mevzuun güzelliğiyle mütenasip zuhur ediyor.

\section{On Beşinci, On Altıncı, On Yedinci Mebhaslar}

On beşinci mebhasın nihayetlerinde Silvio bir hayli mertlik, bir hayli hak-şinaslık göstermiş ise de ihtiyar ettiği mekânetteki muhakemelerine nazar olunursa kendinin vatanperverlik vazifesine muhabbetini değil esaretini gösterir. Hele mebhasın evvelleri yine aile muhabbetinin kalbinde her hisse galip olduğuna bir delil-i diğerdir. Tercümenin letafeti bunda da mevzu ile mütenasip düşmüş. Aşağıları pek güzel, üst tarafları adi.

On altıncı mebhasın mevzuu hissiyat-ı ulviyye ve hayâlât-ı şâirânenin en ziyade pertev alacağı yerler iken Silvio, arkadaşının felaketinden dolayı gönlünde kız çocuklar[1] gibi mahzunluktan başka 
hissedecek bir şey bulamamış! O kadar parlak bir maddeyi ücretle şunun bunun ölüsüne ağlayan Mısır karılarının tesirsiz enînlerine benzetmiş! [Hiç vatanperver kendi fikrinde bildiği bir adamı zulüm altında esir ve muhkir görür de kalbinde mahzuniyet mi hisseder.] Kuvve-i gazab, şevk-i intikam, takdir-i meâlî, iftihar-ı sevâbık, kin-i ta'addî gibi hasail ne türlü ahvâlde meydana çıkmak için yaratılmış? Bu mebhasın da tercümesini beğenmedim, sebep de içindeki sstılah-perverliktir.

Fıkranın bir yerinde "esbâb-ı politika" terkibini kullanmışsın. Babıali’nin bu yolda olan galatât-ı fahişesini edebiyata da mı nakledeceğiz?

On yedinci mebhas da bütün bütün münasebetsiz. Demek ki Silvio [muhalefet meydanına atıldığı vakit istintakları, hapisleri, cellatları, felaketleri hiç düşünmemiş.] İşe bayağı ticarete girer gibi sellemehü’sselam girmişse de [mahpese] düştükten sonra nazarında beliyyât-ı hâileden ma'dûd olan ve fakat politika işiyle uğraşanlarca umûr-ı âdiyeden bulunan hâllere o vakit nefsini alıştırmaya kalkışmış. Bu hareket ayniyle tüfek atmayı muharebe meydanında öğrenmeye çalışmak kabilinden olmaz mı? Kont Bru'yu görmekle ağlamaya kalkışacak kadar teessür nedir? Silvio otuz yaşında [bir inkılab-cûy] iken adeta çocuk mizacında imiş ya! Bir de farz edelim ki Silvio şu kitabında politika bahsinden keff-i lisan etmeyi her nedense kurmuş. Kaza ile olsun vatanı için kaleminden bir kelime-i teessür damlamak yok mudur? Hele hiddet ve hod-perestliğe dair müellifin nihâyet-i makalede irad ettiği sözler benim anlayacağım hikmetlerden değil! Silvio evvela kâinatı nahvet ve zimamlık ve yek diğere adavetle itham ediyor ki hakikat-i hâl hiç de öyle değildir. Saniyen bu şenayi’i nizam-ı âleme bâis tutuyor ki fikri sahih olmak lazım gelse insan, nizamı rezail ile kâim olan âlemin bir saat evvel yıkılmasına dua etmekten başka söz bulamaz. Hele [insaniyet düşmanlığını nizam-ı âlemin bâis addeden bir adam. İnkılap taraftaranı arasında nassl karışmış? Ona bütün bütün hayret ettim.] Tercümenin kafiye kesretinden başka şikâyet edecek bir yerini görmedim.

\section{On Sekizinci, On Dokuzuncu, Yirminci, Yirmi Birinci Mebhaslar}

On sekizinci mebhasta Silvio yine tıfl-ı bî-zebânı görmek, Madlen’i düşünmek, haydutlardan kızın söylediği türküyü işitmek, kendine muadil bir felaketzede ile konuşmak gibi bir hissiyat-ı rakîka cem etmiş ki tabiatının o cihete olan incizabını bu kıtayla tasvirde gösterdiği maharet bir kat daha ispat eder. Tercüme kafiye esaretinden bütün bütün kurtulmamakla beraber güzel.

On dokuzuncu mebhas bir sergüzeşt naklinden ibaret oluyor. Hikâyede şart olan sadelik yerinde olduğu gibi zât-ı mesele dahi şâirânedir. Tercüme güzel olmuş. Fakat biraz daha sade olsaydı daha güzel olurdu. Mamafih böyle hikâye yolunda olan âsâr-ı şi'riyye yazıldığı lisanda okunmadıkça tamamıyla lezzet veremez.

Yirminci mebhasın mevzuu da on dokuzuncu mebhas kadar şâirâne olduğu gibi sonralarına doğru içinde bir de güzel ahlak dersi var. Tercümenin iptidaları pek nefis. Fakat yüz on dördüncü sahifenin on ikincisi olan "dürûd-ı meviza ve nasihati" sözleriyle başlayan satırdan aşağısına birtakım eski ve münasebetsiz teşbihlerle bir hayli lüzumsuz kafiyeler, ıstılahlar karışmış.

Yirmi birinci mebhas müellifin bir muhasebe-i nefsiyle bir ahlak dersinden ibaret olarak mevzuu pek şâirâne değilse de makrûn olacağı hakikatten bir ulviyet kazanıyor. Tercüme âlâ, fakat kusurdan berî değil. Ez-cümle bir fena te'kit var ki şu ibaredir: "Ben ki uluhiyeti ikrar ve kabul ve onun menzelesini tasdikten nükûl etmek fenn-i mantıkı rahne-dâr etmedikçe mümkün olamayacağını pekâlâ kanmıştım." İbarenin ekser yeri kafiyeli olmak cihetiyle rabıtaları daima kafiyede aramaya tabiat alıştığından 
kabulden sonra olan vav, mabadında olan "nükûl" kelimesine kadar makabline atıf gibi görünüyor da ibareden bütün bütün hilâf-ı maksat bir mana çıkıyor.

Bana kalırsa bu su-i iltibastan tevakki için "kabul" yerine "kabulden” denilmeliydi.

\section{Yirmi İkinci, Yirmi Üçüncü, Yirmi Dördüncü Mebhaslar}

Yirmi ikinci mebhas yine bir hikâyeden ibaret olduğu için tabiat-ı şâirâneye o kadar büyük bir cevelangâh değildir. Şu kadar denir ki hem güzel yazılmış hem güzel tercüme olunmuş. Mamafih tercümenin letafetini “heyecan-engîz, vicdan-ı nâ-şekîb" gibi kafiyecilik belasıyla ihtiyar olunmuş birtakım tetabu'ui izafat leke-dâr ediyor. Mevzuun lezzetini Silvio'yu yağmur bulutu gibi her tebeddül vuku buldukça yaş dökmeye icbar eden hissiyat-ı zen-mizacâne bozuyor. Hele otel hizmetçisinin kendini bilip de bazı ahbabına haber vereceğinden dolayı müellifin memnun olmasına bir mana veremedim. [Zaten kendisi mahpeste ihtilattan memnu olacak. Bu hâlde ahbabı, felaketini duyarsa kendini göremeyecekler. Yalnız müteezzi olacaklar.] Bilemem ki bir insana göre kendi için ahbabının kederlenmesine memnun olmak makbul bir haslet midir?

Yirmi üçüncü mebhasın sadeliği ve hüsn-i sebki nihayet derecelerde güzel olduğu gibi tercümesinin letafeti, içindeki bir iki atf-ı tefsiri ile beraber mevzuundan geri kalmıyor. Vakıa Silvio buna da aile gailesini karıştırmış. Fakat yalnız inkıta'-ı haberden ibaret olan şikâyeti her türlü itirazdan berî bir dairei itidal içindedir.

Müellif yirmi dördüncü mebhasta bütün bütün yâve söylemeye başlyyor. [Politika töhmetiyle muhakeme altına düşmek neden o kadar dehşetliymiş. Acaba muhakemeden evvel vicdanı önünde bir şiddet-i takatfersa ile müttehem olan bir katil veya sarkın muhakemesi meslek-perverlik ağverinde hasmın pençesine düşmüş bir sahib-i namusun istintakından daha mı dehşetsizdir? Yahut eşedd-i mecazeti mevt olan bir kabahatin daha istintakından intihara kalkışacak kadar korkmak erbab-ı gayret kârı mıdır? Ya biz] İtalya'nın Avusturya devletinden teaddî, ya eziyet gördüğu için adalet-i ilâhiyece şüpheler peydâ etmesini ve onun neticesi olarak meziyet-i fazileti inkâr ettikten sonra âlem ve âlemiyânı da sezâ-yı nefrîn görmesini hangi mantığa sığıştırabilelim? Cahil, bir had ve bir zaman-ı felakette hod-perestliği kendini adalet-i mutlakadan muhikk görmek ve nefsine taraftar bulamadığı için umum insaniyeti hasmıyla müşterek göstermek derecesine götürebilir. Silvio gibi gerek zekâvet ve gerek terbiyece mütemeddin bir millet içinde fevkalade bir şöhrete mazhar olmuş bir adamın velev muvakkat olsun o kadar sakîm fikirlere düşebilmesine ne kadar taaccüb olunsa şayeste değil midir? Dikkat et ki zaaf-ı kalp en kemalli zannolunan insanları ne mertebelere tenzil ediyor! Vakıa müellif bu efkâr-ı garibesini hikâyeden sonra tehevvürün seyyiatına dair bir güzel ders-i hikmet tahrir eylemiş. Fakat o hakikatleri halka talim edeceğine herkesten evvel kendisi zaman-ı felaketinde onlarla âmil olmak lazım gelirdi. Silvio gerek İncil-i muharrefinden ilk açışta nazarına tesadüf eden sözleri ve gerek çocukla olan muhaveresini mahirane tarif etmiş. Tercüme de pek güzel, âh işin içinde o kadar atf-ı tefsir olmasa!

Yirmi beşinci ve yirmi altıncı mebhaslar. Müellif diyanete avdette bulduğu lezzeti, hissiyat-ı şâirâne ve tasvirat-ı hakîmâneden mürekkep bir eda ile fevka'l-gaye güzel tarif etmiş. Vakıa işin içine biraz da girye karıştırmış ise de Hâlık-ı azimü'ş-şâna tezellül makamında dökülen yaşlar zaaf-ı kalpten değil, hadd-i ubudiyeti idrakten ileri geldiği cihetle bir fazilettir. Yalnız bir sözüne taaccüp ettim; o da "ağlamak nefsimce pek müşkül iken" lakırdısıdır. Mübarek ağlamakta bu kadar suûbet gördüğü hâlde hapse girer ağlar, babasını görür ağlayacă̆ı gelir; ahbabıyla görüşür kendini ağlamaktan zorla men eder. Demek ki girye hususunda biraz da nefsince suhulet görseymiş selam verseler ağlayacakmış! 
Bu mebhasın tercümesini mevzuu nispetinde bulamadım. İçinde kafiye yoluna hüsn-i ifadeyi feda gibi, çirkin teşbih gibi tetabu'-ı izâfât gibi, lüzumsuz atıf tefsiri gibi nekâisin hepsinden birer ikişer bulunuyor.

Şimdi hatırıma geldi; bilmem ki kitabın asıl İtalyancası mevzun mudur? Ĕger mevzun ise İtalyan şiirinin bu kadar cüz’iyatı hikâye ve tarife müsait olmasında dolayı bizce ne kadar gıpta olunsa şayestedir.

Yirmi altıncı mebhas eğer i'dam-ı nefs tasavvuru ve çıldırmak korkusu gibi zaaf-ı kalbin eşnâ-ı denîâtı gibi olan iki münasebetsizlikle leke-dâr olmasa kitabın en şâirâne yazılmış parçalarından biri olurdu. Hele karınca beslemek hususu başıma geldiğinden midir nedir pek zevkime gitti. Benim burada bir alay karıncalarım var. Yazıdan, okumadan kesel geldiği zamanlar yanımda kimse bulunmazsa onlarla eğleniyorum. Hatta geçen gün ben yanı başlarında iken o aceze gayretinin misâl-i zî-hayâtı olan hayvancıklar koca bir sinek ölüsünü sürüye sürüye deliklerinin ağzına götürdüler. Kendilerinin güç ile sığabildikleri menfezden bin türlü himmetlerle koca sineği geçirmeye muvaffak oldular! Ben de iki saat kadar onları seyrettim. [Hem de Osmanlı kumandanlarının halefi olacak millette karınca kadar gayret kalmadığını düşünerek büyük büyük teessüfler ettim.] Sivrisinekten şikâyette de Silvioyu haklı buluyorum. Fakat kendini öldürecek veya çldıracak mertebe şikâyette değil. Mübarekler burada insana göz açtırmıyorlar. Şimdi şu yazıyı yazarken vücudumu yoklasalar üzerinde laakal otuz kadar sivrisineğin yarası bulunur. Yara dediğime taaccüp etme! Bunlar İstanbul'da gördüğümüz sivrisinek kabilinden değil, bayağı her biri ufak arı kadar; soktukları yer kanıyor. Bakla kadar şişiyor. Veca saatlerce sürüyor...

Zannederim ki sıcaktan şikâyet etmekte benim hakkım Silvio'dan ziyadedir. Bu sene havalar ehvence geçti ise de geçen sene bir duvara iki karış kadar yaklaşmak bayağı ateşe girmek hükmündeydi.

Mebhasın tercümesi ekseriyet üzere pek güzel olmuş; fakat yine içinde kafiyecilik de var, ıstılahperverlik de var.

\section{Yirmi Yedinci, Yirmi Sekizinci, Yirmi Dokuzuncu, Otuzuncu Mebhaslar}

Yirmi yedinci mebhasın gerek mebadisindeki hüküm ve gerek evahirindeki tahkiye pek güzel yazılmış. Eğer içinde "nûş-ı zehrâbe-i memat" gibi birkaç köhne ifâdât olmasa tercümesi de letafette yazılışıyla müsavi derdim.

Yirmi sekizinci mebhas gayet şâirâne tasavvur olunmuş. Vakıa açlık âlemlerinde hayale ne derece galeyan geldiğini ben de tecrübe ettim. Hele göz önüne bir âdem alınsın ki zengin, zeki, terbiyeli, refahiyet içinde ${ }^{19}$ büyümüss olduğu, [vatanına hizmet dâiyesinden başka bir kabahati olmadığı hâlde zindana atılmış ve] bir gece açlığı ihtiyar ederek eline birkaç tane kâğıt parçası geçirmiş de yanaklarının buruşukluğu, çehresinin renksizliği, gözlerinin baygınlığı ile beraber masa kenarına oturmuş. Kâffe-i ezkiyânın mahbûb-ı kulûbu olan hikmet ve edebe hizmet için sabaha kadar it'âb-ı efkâr ediyor. Dikkat olunsun bu tahayyül gönülde ne müessir halecanlar, fikirde ne âlî tasavvurlar peyda ediyor. "Zanaz" ile mükâleme eğer Silvio'nun ihtiraât-ı fikriyesinden değil ise feleğin bir şairlik zamanında hâsıl olma tesadüflerindendir; denilmek lazım gelir. Mamafih vak'a sahih olsa bile gerek intihab ve gerek tasvirinde olan maharet müellifin tabiat-ı edibanesine medar-ı mefharet olacak bedâ’idendir.

Tercüme de her türlü sitayişe layık idi "pister-i mihnet gösterme üftân ve ganûde-i hâb-ı girân” kafiye ve terkipleri koskoca bir ibarenin bütün bütün letafetini kaçırmış olmasa idi.

19 Bu ifade ikinci nüshada "refah ile" şeklinde geçmektedir. 
Yirmi dokuzuncu mebhas da letafette yukarıda bahsettiğim iki makaleden aşağı kalmıyor. Tercüme yukarıki fikralara faik olmakla beraber yine bütün bütün kusurdan sâlim değil; evvela "hammât" kelimesi "müsârefât" gibi lisan-ı resmî galtatından olarak âsâr-ı edebiyyede yer bulabilecek tabirlerden değildir. Malumdur ki kavaid-i Arabiyye hükmünce cem’-i bade'l-cem, cem-i mükesser vezninde gelemez. Saniyen "zan ve güman" yazmakta bir mana, bir letafet yoktur zannederim.

Otuzuncu mebhasın tasviri de âlâlardan âlâ. Fakat tercümesinde yine şayan-ı muaheze yerler var. Tercümenin letafeti gittikçe ziyadeleştiğinden ben de bu mebhastan itibaren müşkülpesentliği o nispette ziyadeleştiriyorum:
1. Lisan-1 edebin asrımızda en maruf olan kelimelerinden "aile" dururken "familya" tabirini kullanmakta bir mana göremem.
2. Şekîb kelimesi ihtimal ki sıfat-ı müşebbehe olarak sabır manasına da gelir; lakin lisan-ı Osmani’de daima isim olarak "sabır" manasına istimal oluna geldiğinden "şekîbâne” tabiri "sabırâne" gibi manasızdır sanırım.
3. "Dûçâr-ı havf ve hiras" ibaresindeki havf ve hiras kelimelerinin biri ziyade değil mi?
4. "Hissiyat-ı safvet-karâne-i kûde-kâne" yerine, safvet üzere birtakım hissiyat-ı masumane denilse daha güzel olmaz miydı?
5. "Şûrîde-hâtır eylerse de" yerine gönlüme dokunursa da denilse daha fasih, daha vazıh düşmez miydi?
6. "Edibane nazar bir zemin ve humret-i hicap ile ârız-ı ateşîn oldu” Telemak kokuyor.
7. "Ser-safha-i kalb” yeni lisan tabirlerinden değil.
8. "Menkuş ve mahkuk" kelimelerin biri varken diğerine ne lüzum görünür?

Sonradan gördüm tercümede bir de "umur ve husûsât” tabiri var ki en çirkin atf-ı tefsirlerin biridir.

\section{Otuz Birinci, Otuz İkinci Mebhaslar}

Otuz birinci mebhas ders-i ahlak ile bedâyi-i şiiriyeyi cem' etmekte akranı nadir görülen âsârdandır. Tercümesi de pek güzel; mamafih yine bazı yerlerini muahezeye kendimde mecburiyet görüyorum: "Dûçâr-ı hadşe vü telaş bulunmaya idim" ibaresindeki hadşe ve telaş kelimelerinin biri ziyade.

"Sahne”ye kafiye olmak için yazdığın "hande-i şeker-şiken" tabiri sinirlerime dokunuyor. Öyle gülle şekeri kırarken çeçikten çıkan sedaya benzer kahkahalar ne kadar latif olur değil mi?

“Tahrîk-i mervaha ve dest-mâl iden sâid-i nermîn-ten" ibaresinden maksat gah çevre, gah yelpaze sallayan nazik kolları mı demek olacak?

"Gönlüme kûde-kâne neşeler îsâr" ibaresindeki "kûde-kâne” yerine "masumane" denilmek buraca dahi makama daha münasip idi zannederim. Bir de îsâra kafiye yapmak için devamın altına koskoca bir "istimrar" yazmakta letafet yoktur sanırım. "Gussa vü melal" ve "pend ve nasihat" ve "hazz ve mesarr" atıflarının hiç arkası kesilmiyor!

Otuz ikinci mebhas birkaç nevi ezhar-ı hayalden mürekkep bir güldeste-i letafet vasfına layık görünür. Mamafih içinde bir sebze-i hasis dahi mevcuttur ${ }^{20}$ : O da Silvio'nun hâlinden şikâyet etmemeye müddeti medîde [inkılap taraftarlığı ettikten ve iki sene kadar mahpus] kaldıktan sonra alışabildiğine dair îrâd

2o İkinci nüshada bu ifade "görünür" şeklindedir. 
eylediği itiraf kûd-kânedir. Tercüme heyet-i umumiye itibariyle güzel, fakat bir hayli şayan-ı tariz yerleri var:

Evvelen "gûş-dâde-i itimat" terkibinden mana çıkarmak tevil-i ba'îde muhtaç. İtimat sâmiâya ait bir hassa değildir ki itimat kulağını verdim denilmek belagaten caiz olabilsin.

Saniyen "me'yusü'l-fuâd” terkibi hiç isti'mâl olunmamış olduğu hâlde fuâd lafzının ilavesiyle me'yus kelimesine bir zâid mana inzimam etmediğinden kabul ve ihtiranna dahi edebiyatça katiyen ihtiyaç yoktur. Dikkat ediyor musun! Edebiyat-ı atikadan bütün bütün tecrit etmedikçe kafiye zarureti bayağı para zarureti gibi insanı ne kadar münasebetsiz şeylere sevk ediyor.

Salisen "dehşet-i vahşet oldu" terkibindeki "hücnet" sözünü mukteza-yı hâle mutabık göremedim. Yanımda lügat yok. Fakat eğer hafızam beni aldatmıyorsa hücnet kelimesi ayıp ve mahzur manalarına olacak. Halbuki Silvio'nun zindan-pend edilmesinde ayıp ve mahzur tevlit edecek bir hâl göremiyorum.

Rabian "âfâk-ı eyyâm-ı felâketimde" ne demek? Mekâna mahsus olan ufuk ki mesafe-i rü’yetin incizâb1 arz ile hâsıl olan hadd-i intihasından ibarettir; zaman aksamından olan eyyamda nasıl bulunabilir?

Hâmisen "def ve teb’îd" kelimelerinin yine biri zâid olduğu gibi onun kafiyesi olarak kullanılan "hayat-ı cedîd" terkibinde sıfat mevsuf mutabakatı yok. Vakıa itimadımca bu mutabakat kat'iyyü'l-lüzum değildir; fakat kafiye-perverâne ve binaenaleyh edebiyat-ı atikaya mail bir tarzda yazılan şeylere de tezyinattan evvel kaideye ittiba etmek iktiza edeceğini tarif iktiza etmez.

Sâdisen “mahv ve münkesir mi eyledi?” terkibini kullanmak nasıl caiz olabilir. Bir şey mahvolduktan sonra münkesir olmasına imkân mutasavver midir?

Sâbien "feryad ve figân", "hareket ve heyecan" ibarelerinden feryat ile hareket kelimeleri iskat olunsaydı manaya değil kafiyeye bile halel gelmezdi.

Sâminen "mahcub ve şerm-sâr olmakta bulunmuşum" terkibindeki kafiye mütalaası dahi yok iken yine bir söz yerine iki kelime kullanılmıș!

Tâsiân en maruf tabirlerden olan "müthiş" kelimesi meydanda dururken belki âsâr-ı kadîmede bile bir kere istimal olunduğu görülmeyecek kadar garip olan "dehîş" kelimesini kullanmakta bir hikmet tasavvur edemem.

\section{Otuz Üçüncü ve Otuz Dördüncü Mebhaslar}

Otuz üçüncü mebhas lezzetle okunacak bir hikâye ise de müellif aldığı mektubun ötesini berisini terhim ederek fikranın lezzetini kaçırmış. Tercümenin bî-had ve payan atıflardan başka kusuru yok.

Otuz dördüncü mebhasın mukaddematı hissiyât-ı ulviyyece üdebaya misâl-i imtisal olmaya şayestedir. Fakat hayalat ve teşbihatta şark âsâr-ı cedidesinin madununda kalıyor. Evahiri ise Silvio'nun zaaf-ı kalp ve fart-ı vehmine en büyük delil olacak makalatındandır. Rast geldiğine emniyetsizlik eden dünyada emin dost bulamaz. "Nefsimde tecrübemle inan söylerim sana" insan saadette bulunsun, felakette bulunsun tabiat-ı beşerin meyl-i mehâsin ile mecbul olduğuna ne kadar itimat gösterirse o kadar hüsni efâle tesadüf ediyor. Tuğrâyînnin "Ve enmâ ricâlü’d-dünyâ ve vâhdehâ / Men lâ ye’ûl fi'd-dünyâ âlî- 
rical” beyti zahirde bir hikmet-i âliye gibi görünürse de hakikat-i hâlde hod-pesendliğin en cemiyetli bir tarif-i nâzikidir.

Gelelim tercümeye: "Zat-ı meçhul-şahıs" terkibi çirkin görünüyor. Yerine o şahsını bilmediğim zat denilse daha parlak olurdu sanırım.

"Ferah ve inbisat” kelimelerinin birinden birine lüzum yok.

"Muharririni yüz defa tarziye eyledim" ibaresindeki "tarziye" tabiri ıstılahta ashab-ı kirâm ile bazı ecelleye mahsus iken bir Hıristiyan hakkında kullanılmasında cevaz göremem. [Vakıa biz Gülşen-Seray muharriri Şakir ve Hoca Sadık merhumlar hakkında tarziye yazdık. Fakat onlar hem Müslüman ve hem de hamiyet-i vatan kuvvetiyle İslam arasında mukaddes idiler. ${ }^{21}$ Bununla beraber o sözden muradımız tarziyenin mana-yı lagvîsi olduğunu tasrih eyledik.]

"Tabirât ve elfâzı sahibinin ulviyyet-i cenabına delâlet ederdi" cümlesinde olan "tabirât ve elfâz" kelimelerinin biri zâid. Saniyen lisanımızda ulviyyet, bizatiha müsta'mel ise de cenâb ile ulvvc kelimesi terkib-i evveline geldiğinden "ulviyyet-i cenâb" isti’mâle mugâyir.

Salisen zat-1 ifadede mantık yok; çünkü "tabirât ve elfâz" hiçbir kâilin ulv-i cenabına delalet eder âsârdan değildir. Hasâis-i kalbiye-i rûh-ı kelâm olan manadan bilinir. Bir âdemin sıfatına elfâzından hükmetmek elbisesinden hükmetmekle beraberdir.

"Hücnet-nümûd olan bir fikr-i redâet-alûd" ibaresinde dört tane kafiye var, fakat hiç letafet yok.

"Esrâr-ı hafâyâ", "vahtiyât ve intibah", "havf ve haşyet", "farz ve takdir", "me’âş ve vazife", "nesâyih ve vesâyâ" terkiplerinde olan ikişer kelimenin birer tanesi olduğu tarife hâcet olmamak gerek.

\section{Otuz Beşinci, Otuz Altıncı Mebhaslar}

Otuz beşinci mebhas o kadar şâirâne bir şey değilse de lezzetle okunacak bir hikâye olduğu gibi müellifin kaleminden gayet mahirane bir tarzda çıkmış. Vakıa bazı yerleri Silvio'nun vehmine delalet eder. Fakat gösterdiği ihtirazlar nefsine değil hayır-hâhane kendiyle muhabere etmek isteyen ve o muhaberenin men'ine memur iken cereyanına vâsıtât-ı fedakârlı̆̆ında bulunan iki adama ait olduğundan takbihe değil bilakis takdire şayestedir.

Tercümede nazar götürür bir hayli şeyler var. "Ezcümle ahvâl-i müşkilede Cenâb-ı Hak ile halisane istişare eylemek” ibaresindeki istişare şive-i lisan hükmünce hem Cenâb-ı Hak’tan taleb-i işaret ve hem de haşa Allâmü'l-guyûb'a talim-i hikmet gibi birtakım mana ifade ediyor. "İstişare" kelimesi mana-yı mevzuu itibariyle taleb-i işaret manasına istimal olununca "Cenâb-ı Hak ile" yerine Cenâb-ı Hak'tan ibaresi kullanılmak, yani Cenâb-ı Hak’tan halisane istişare denilmek iktiza ederdi itikadındayım.

"Havf ve haşyet" bu mebhasta da tekrar eylemiş! Türkî izafetlerin de tetâbbuu yakışıksız düşüyor. "Neşe ve lezzetten daima keşîde olarak” ibaresinde belagat yok. Neşeden etek çekmek nasıl olabilir? Onun yerine fâriğ olmak denilse güzel olurdu sanırım.

${ }_{21}^{21}$ [Bunu Şakir'in vefatı üzerien Hadika'da merhumun mektubuyla neşrettiğim makalede ve Sadık Hoca'nın vefatını ilan sırasında da Sirac gazetesinde ben yazdığım gibi Kemal de İbret gazetesinde yazmıştı. Burada "biz" tabirini istimali bu sebepledir. Hadika'daki ibare şöyledir: "Rahmetullahi aleyh... tabirde hata varsa mazur tutulsun "radiyallahu anha" yani millet kendinden razıdır; Allah da razı olsun.”] (dipnot metne aittir) 
"Nişâne-i bî-bahane"de kafiye var, mana yok. Bahane bulunmaz, veyahut bahanesiz nişâne de demek?

“Tarif ve tezkâr”da tezkâr atfı "sa’y-ı bî-şümâr”daki bî-şümâr sıfatı zevaitten.

Otuz altıncı mebhas gayet hassasane bir yolda yazılmış. Joli'yi müellife olan tarizatında haklı görüyorum. Diyanet aleyhindeki edepsizlikleri olmasa metanet-i ahlakça herifi Silvio'ya müreccah tutacağım. Bununla beraber Joli’nin dinsizliğini de o kadar ta'yib edemem. Çünkü ekânim-i selase üzerine mübteni olan Hristiyanlık mezhebi hiçbir âkilin kabul edeceği akâidden değildir. Bir zihinde ise taaddütü'l-vahyeti ya nefiy veya ispat ile vacib-i fikrinin vahdet ve kutsiyetine halel geldikten sonra vücûd-ı Hâlık itikadını da ret ve belki inkâr şaibelerinden kurtarmak pek büyük dirayete, pek çok muhâkemat-ı fikriyeye tevakkuf eder.

Tercümede “akd-i rişte-i münasebet” ibare-i köhne-edasından başka bir kusur göremiyorum.

\section{Otuz Yedinci ve Otuz Sekizinci Mebhaslar}

Otuz yedinci mebhas hikmet ve ahlakça bir ders-i marifet olabilecek kemâlât-ı edebiyyedendir. Tertib-i şâirânesi de pek güzel.

Tercümesinde "biâr ve halîü’-a'zar”, "ıstırap ve pîç-tâb”, "şükûk ve şübhât”, "sıdk ve rast-gûy”, "hiddet ve tehevvür", "cenk ve sitiz", "delâil ve berâhin" gibi atf-ı tefsirîler olmasaydı yalnız iki kusur bulunabilirdi. Bunun biri "küfr ve ilhadın zaaf ve nehafeti” cümlesindeki "nehafet" tabiridir. O da zaaf manasına ise de maneviyat ve mücerredatta isti'mal olunmaz sanırım.

İkincisi “dil-i âzurde-i sihâm-ı istihza” terkibindedir ki pek Acemâne bir şivede görünür.

Otuz sekizinci mebhasın mevzuu da bir maharet-i kâmilane ile tasavvur edilmiş. Tercüme âlâ, lakin içinde şu kusurlar var: Hikmet ve felsefenin ikisi de bir manaya iken ikisi de yazılmış. "Şükûk ve şübhât ve sıdk ve rast-gûy" atıfları bu mebhasta da tekerrür eylemiş. "Arzu vü meyelan" ve "zekâ vü fetanet" ve "zann ve gümân” ve "tesir ve infial” ve "afv ve iğmaz" kelimelerinin birer tanesi zaittir.

\section{Otuz Dokuzuncu, Kırkıncı, Kırk Birinci Mebhaslar}

Üç makalenin cümlesi de hem şâirâne hem de sahihen ibret-bahş olacak derecede hakimânedir.

Otuz dokuzuncu mebhasın tercümesinde şayan-ı tariz gördüğüm “akl ve zekâvet” ve "beyan ve izah” ve "delâil ve berâhin" atf-ı tefsirîleridir. Kırkıncı mebhastaki "çünkü bu tîzdegî-i hiffet ve küstâhî çağının elbette bir hengâm-ı dil âsûdegî-i temkin ve istihyâ ile...” cümlesi pek Acemâne düşmüş. Onun yerine bu hiffet ve küstahlık hummalarının temkin-i istihya sekiniyle... denilmiş olsa imiş ne kadar güzel düşecekmiş.

“Kurban vü kurban”22 gibi cinaslar şathiyatta pek tatlı düşebilirse de âsâr-ı ciddiyenin ağırlığını bozuyor.

22 Meâhiz-i iştikakları bir olan iş bu kelimeteyden biri zamm-ı kâf ile Cenâb-ı Hakk'a vesile-i takarrüp olan takdeme-i ma'rufede diğeri ise kesr-i kâf ile zikri müstehcen muamelede istılah olmuştur. Nitekim Ethem Pertev Paşa "havatin-i sanem simalara karban için hakikati kurban etmekte” ibaresiyle ıtlaku'l-inkâr gibi en ciddi bir eserden cinas-perdazlık seyyiesinden kurtulamamış ve görünüyor ki Ekrem Beyefendi de o esere ıktifadan kendini alamamıştır. (dipnot metne aittir) 
"Mazhar-1 dest-zenî-i sâpâş" ibaresi de pek köhne-eda. "Sâpâş" kelimesi galattır. Sahihi ser-baş23 olacak ki "sarpaş"tan ${ }^{24}$ mahfuf... Onun yerine de birinci tahsinlerle alkışlayacağı denilse hem daha latif hem daha vazıh olmaz mıydı? Bu mebhasta bir de "hiddet-i gazap" sözü var ki elbette aslı hiddet ve gazap olarak mürettep efendilerimizin marifetiyle vavı sâkıt olmuş olacak. Mamafih iki kelimenin matuf ve matuf-ı ileyh oldukları hâlde yine biri zaittir.

“Tezyîn-i hâtır-ı muhabbet-bedîd” ibaresi üstündeki "güft-i şenîde” kafiyeli düşmüş ise de vuzuh ve letafetten bütün bütün ârî görünür.

"Mahrum ve hâib” kelimelerinde de yine kafiye-perverlik sâikasıyla zait kelime yazılmak nâkısası ihtiyar olunmuş.

"Yüreğim pür-halecan oldu" ibaresinde mantık bulamadım. Halecan ef'aldendir. Maddiyattan değildir ki onunla bir şey dolmak kâbil olabilsin! "Rişte-i münasebet ve muhabbeti kurmayacakları"25 tabirinde olan "rişte-i münasebet" ifadesi hem köhne eda hem belagatsiz. Münasebet ve muhabbet irtibatlarını ipliğe teşbih etmekte ne muhsinat olabilsin? Rişte kadar suhuletle inkıtar kâbil olan muhabbetin ne hükmü olabilir?

Kırk yedinci mebhasta yine "sükût ve hâmuş ve kelâl ve melâl" atıfları var. Eğer onlar olmasa bu bahsin tercümesi belki her bahsin naklinden daha mahirane addolunmaya şâyân ${ }^{26}$ idi.

\section{Kırk İkinci, Kırk Üçüncü Mebhaslar}

Kırk ikinci mebhasta müellif kalbin en rakîk hissiyatıyla zulme muinlerinin şiddet-i mudhikelerini tamamıla gösterecek bir hikâye mezcederek güya ki Verudi'nin nagamat-ı hazîniyle o Kanbeha'nın²7 hande-rîz ahenklerinden mürekkeb bir fasl-ı garîb tertip eylemiş. İnsan okudukça tabirat-ı marufeden olan "bir gözü ağlamak, bir gözü gülmek hayalini” vücuda getirecek zannediyor.

Tercümesinde şayan-ı nazar birtakım yerler var: Terkibin kafiyesi olan "siz" adeta terkib-i izafi âhirine geldiğini gördüm. Onun için bana "ariza-gözsüz” terkibi bir tabiat-ı selîmin kabul edemeyeceği derecede garip göründü. "Şiddet-i hararet-i hava kesb-i itidal eyledi." Terkibinde mantık yok. Hava itidal hasıl eder. Hak ifadece hava şiddet-i hararet hâlinde iken kesb-i itidal eyledi denilmek lazım gelirdi.

"Benim mahud karıncaları kemâl-i ihtimam ile ve eğer tabiri gülünç olmazsa şefkat-i maderane ile terbiye ve infak edişim" ibaresindeki "terbiye" tabirinde mukteza-yı hâl yok! Karınca, maymun veya köpek değildir ki terbiyesi kâbil olabilsin.

Mebhasın sair cihetleri tabiat-ı edibanene layık olacak derecede güzel tercüme olunmuş.

Kırk üçüncü mebhas pek şâirâne ve garîbâne yazılmış. Şu kadar var ki Silvio'nun hissiyat-ı vatanperveranesi tabiat-ı şâirânesi kuvvetinde olsaydı bir maksad-ı mukaddes yoluna gördüğü zulümden dolayı hiç bilmediği çocuklardan, kadınlardan gördüğü muhabbetler, hürmetler üzerine garipliyeceğine

Bu ifade ikinci nüshada "şâpâş̧" şeklinde geçmektedir.

Bu ifade ikinci nüshada "şâd-pâş" şeklinde geçmektedir.

Bu ifade ikinci nüshada "kurmayacaktı" seklinde geçmektedir.

Bu ifade ikinci nüshada "şayeste" şeklinde geçmektedir.

Bu ifade ikinci nüshada yoktur. 
fikrine bir ulviyet, kalbine bir mefharet gelirdi de hiç olmazsa birkaç satır olsun meslek-i hamiyetin âlem-i insaniyetten gördüğü mükafatları takdis ederdi.

Bahsin tercümesinde ibraz ettiğin marifeti tebrik ederim. İçinde tariz kabul eder bir harf göremedim.

\section{Kırk Dördüncü, Kırk Beşinci, Kırk Altıncı Mebhaslar}

Silvio kırk dördüncü mebhasa, ahbaba teessüf gibi insaniyetkârâne bir hissi testir-i fikr-i bâtılı ile mezc ettikten sonra gerek o mebhasta ve gerek onu takip eden iki makalede zaaf-ı kalbinin netâyici olan birtakım hâlât-ı sevdâvîye tasavvur eylemiş. Vakıa bunlarda bahsettiği hâller bir cism-i alîlin dûçâr olabileceği infiâlât-ı tabiiye âsârından olduğuçün müellif bir kere hastalandıktan sonra o türlü evham içinde kaldığından dolayı ta'yib olunamaz. Fakat mesleğinin netâyicinden olan bir felaket için çıldırmaya yaklaşıncaya kadar müteessir olmak hiçbir sahib-i hamiyete yakışır nekâyıstan değildir. Hele uğradığı hastalığın hezeyanları arasında muttasıl aile ile uğraşması, evini vatanından ziyade sevdiğine, diyanette hâsıl ettiği tereddütler, inkârlar ise hissiyat-ı vicdanının sebatsızlığına, sarhoş ağzından dökülen ve hafayâ-yı kalbiyenin en sadık muarrifi olan kelimât-ı ıztırâriye kadar kutlu delillerdir.

Mamafih uğradığı sevdanın ahvalini pek nekâdâne ve şâirâne cem’ ve tertîb eylediği de inkâr olunamaz.

Gelelim tercümeye: Kırk dördüncü mebhasdaki "garîk-i âb-ı kazâ" ne çirkin ifade! Bir adam suya boğulmakla kazayı suya benzetmekte veyahut suyu kazaya tesbit etmekte ne belagat tasavvur olunabilir?

"Kâbus-ı eâzım" terkibindeki eâzım sıfatında ise kafiye olmaktan başka bir lüzum olmadığı gibi kâbusun küçüğü büyüŭü de olmadığı cihetle birtakım tâvilât-ı ba’ideye kaçılmaksızın manada bulunamaz.

"Kalem be-dest olarak" ifade-i Acemânesinde bir letafet göremedim. Yerine kalemi elime alarak dense idi lisanın edebiyatına elbette daha muvafik olurdu.

"Havişâ" tabiri bu mebhasta da tekerrür eylemiş. "Telehhüf” tabiri edebiyat-ı cedidede müsta'mel değil. Kabulüne lüzum da göremem; çünkü o manayı ifade edecek pek çok tabirler kullanıyoruz.

Bahsin heyet-i umumiyesi pek güzel tercüme olunmuş. Heyet-i umumiye itibariyle kırk beşinci mebhasın da tercümesine tahsinden başka diyecek söz bulunamaz. Ah içinde "medhûş ve hirâsan" ve "endûh ve esef" ve "tarumar ve perişan" atf-ı tefsirleri olmasaydı!

Bir de "ruhsatta eşk-i tufan-hîz" ibaresi gerek lafzen gerek manen pek Acemâne değil mi? Bir de²8 "hâli ducret-i iştimâl" gibi "heyecan-ı ıstırab-nişân" gibi eski divan ifadesi bozuntularının medar-ı mefhareti olan manasız ve köhne eda terkibleri niçin kullanırsın?

Kırk altıncı mebhasta "zann ve güman" terkib sekamı yine tekerrür eylemiş. "Hengâm-ı zalâm-ı leyâlde" yerine gecelerin karardığı sırada denilseydi şiveye daha mutabık gelmez miydi? "Zaîf ve dermânde" kelimelerinin biri zait. "Dâ-i udal hüzün-iştimâl" divan ifadesi kârî bir terkip. "Efkâr ve hâtıra", "havf ve dehşet", "recâ vü istidâ" bin yerde şikâyet ettiğin lüzumsuz atıf tefsirlerinden "lâyık ve sezâ-vâr" kezalik.

"Sem-i huşme" beliğ değil, çünkü akla bir kulak isnadında bir letafet yok. "Azade-girîbân” Acemâne, "mesrur ve şâdân" lâyık ve sezâ-vâr kabilinden. "Sâgar-ı derûnum ser-şâr-ı bade-i şükrân" hem köhneeda hem manasız. Çünkü insanın karnını kadehe, şükranı şaraba teşbih etmekte bir münasebet-i

28 Bu ifade ikinci nüshada "husûsâ" şeklinde geçmektedir. 
edebiyye tasavvur olunamaz. "Kuva-yı vücudiye"de "vücudiye" zait; vakıa kuva-yı cismaniye denilir; fakat kuvve-i ruhaniyeden tefrik için. Kuva-yı ademiye yoktur ki "vücudiye" vasfı kuvvayı ondan tefrik eylesin. Tercümenin sair yerleri pek güzel.

\section{Kurk Yedinci, Kırk Sekizinci Mebhaslar}

Kırk yedinci mebhas pek edibane yazılmış ve fevkalade ve hiçbir yeri tariz götürmeyecek derecede âlâ tercüme olunmuş. Mamafih mevzuu müellifin sima-yı ahlakında zûr-ı vâhime ile hâsıl olmuş ve setrine çalışmakla beraber nazar-ı dikkatten kurtulmasına imkân bulunamamış olan beniz uçukluğu kabilindendir.

Kırk sekizinci mebhasın mebadisinde Silvio nefsine zûr ile ilkâ-yı metanet etmek istemiş ve dirayet ve mantık kuvvetiyle mevt hakkında hayli cesurane ve hakîmâne mütalaalar da meydana koymuşsa da fiiliyat zamanı gelince azminde sebat edip edemeyeceğine dair gösterdiği tereddütlerle hem zaaf-ı kalbine ve hem televvün-i vicdanına bir delil daha göstermiştir!

Silvio'nun tabiat-ı edibanesinde en ziyade kuvvet gösterdiği yerlerden biri ve hayalat-ı şâirânesinin en ziyade parladığı mebhasın birincisi bu makalenin evâhirine tesadüf eden yangın bahsidir ki şimdiye kadar gördüğüm âsâr içinde bundan revnaklı parçalara pek çok tesadüf edemedim.

Tercümede "layık ve münasip", "tefsir ve teârif”, "rastî vü isbât” atıf tefsirleriyle "kâle’n-nakş-ı fi'l-hacer" terkibi münasebetli münasebetsiz o kadar çok yerlerde kullanılmış ki edebiyat arasına karışmak meziyetinden bütün bütün mahrum olmuş. Zaten dahi iktibas olunacak kadar bedi’i bir teşbih değil.

"Safha-i aklımda menkuş ve muharrerdir" ibaresi bütün bütün çirkin. İptida akıl niçin safhaya benzesin? Saniyen menkuştan sonra muharrer veya muharrerden evvel menkuş yazmakta ne lüzum görünür?

“Nâ-bedîd ve bî-nişân” kelimelerinin biri yazılmış olsa ifade veya manaya bir noksan mı terettüp ederdi?

"Ahvâl-i ibret-iştimâl” yollu kafiyeleri, hakikaten "eğer tarf-ı hatırımızdan sual-i şerif erzânî buyurulur ise" tarzında olan arzuhâlci ifadeleri kadar sakîl görüyorum.

"Merdane-gî ve cesaret", "asayiş ve sükûnet”, "memnuniyet ve meserret”, "tezad ve tebâyün” sözlerinin nısfi zait ve sükûnetin doğrusu sükûn olduğunu ihtara hâcet göremem. "Zehrabe-keş-i memat” köhne eda, "leb-i cünban-ı tasdik" kezalik. "Ferce-yâb-ı kalb-i nev-mîd" Nergisiyâne "farz ve tahîl", "memnuniyet ve meserret" nev'indendir.

\section{Kurk Dokuzuncu, Ellinci Mebhaslar}

Kırk dokuzuncu mebhas pek müessir bir yolda yazılmış. Fakat bir inkılap taraftarının değil saadet içinde yaşar ve ömrüne doymamış bir kibar-zâdenin ve daha doğrusu aranılırsa edibe bir kadının kaleminden sâdır olmalı idi.

Mukaddema yazdığım barut modası dehşette Silvio’nun yangınından aşağı değildir sanırım: Mamafih benim hayatım onun teessüratına nispet bütün bütün başka bir tarzda idi.

Tercüme güzel, içinde “zevk ve lezzet” ve "sa’y ve gırret” atıfları olmamış olsa daha güzel olurdu. 
"Mizan-ı akılda vezin" ibaresi edibane değil, vezin kullanıldıktan sonra mizanın, mizan istimal olununca veznin hiç lüzumu yoktu. Hak ifadece onun yerine "mizan-ı akla vurdum" veya "zihnimde veznettim" denilmek iktiza ederdi sanırım.

"Lehib-nâr-ı harîkın beni bel' ve iltikam için odama zebâne-keş vürûd" ifadesinde fesahat yok; çünkü evvela heyet-i umumiyesi bir şive-i lisana mutabık değil. Saniyen, "lehib-nâr" denilince harîk, siyak karinesiyle anlaşlacağından tasrih iktiza etmez. Salisen, lehib ile "zebâne" bir manaya olduğundan lehibin zebâne-keş olması "bâb-ı hümâyun kapısı” kâbilinden olmuş.

Ellinci mebhas. Silvio tercüme-i hâlinin en ziyade nazar-rübâ olan yerlerini müdekkikâne birkaç satıra sığıştırmakda pek büyük bir maharet göstermiş. Ve mebhastan mebhasa naklini dahi pek tabii ve bayağı ressamane denilecek bir tarzda tahrir eylemiş. Bununla beraber mevzuu yine cebânetten, şikâyetten ibaret.

Tercüme güzel, fakat "hücnet" lafzının muktezâ-yı hâle mugâyir olarak istimali bu mebhasta da tekerrür eylemiş. İçinde "müşfik ve mihriban" ve "mutayyeb ve memnun" ve "makrûn ve merhun" ve "hüner ve marifet" ve "karin ve mukâbil" ve "üdeba ve erbâb-ı kalem" ve "avdet ve azimet" ve "erbâb-ı hüner ve kemâl" gibi nısfi zait ifadeler de var.

Bir de "azâ-yı handanımın hacer-i âgûş̧-ı terbitlerinde" ibaresinde âgûşun odaya teşbihini hiç beğenmedim. ${ }^{29}$ Bundan başka "zevat-ı ahbâb-ı fansabdan" terkibindeki "ahbâb-ı fansab" terkibinin soğukluğu bir tarafa dursun, zevat kelimesinin ne lüzumu vardı bilemem? Az kaldı unutacaktım: "Sergirifte-i kemend-i ihnak olacağım” yerine [kemend-i cellada] gerden vereceğim denilse daha şiveli, daha parlak olmaz miydı?

İşte Silvio tercümesine dair mülâhazatım bu kadardır. Huzma safâ da’mâ keder.

Kardeşin Kemal

Magosa

29 [Kemal burada isabet etmemiștir. Çünkü "hacer”in bir manası da aguștur. Hatta "hacer-i Ka'be" ıstılahtandır. Ve hıfz ve himayet manasına müstameldir, ki felanın hacerinde terbit gördü denir. "Kucağında terbiye oldu" manası murad değildir. Meram himayesidir. Mamafih "aguş" lafzı bâlâdaki ibarede zaittir.] (dipnot metne aittir) 